\title{
Chinese Reception and Transplantation of Western Contract Law
}

\author{
Wang Jingen* \& Larry A. DiMatteo**
}

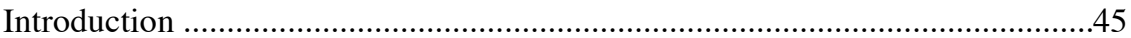

I. Borrowing: Reception and Transplantation in China.....................................46

A. China's Double Transplantation and Resulting Problems...............51

B. Comparative Law as an Avenue to Law Reform ...........................53

1. Perils and Virtues of the Comparative Law Methodology .......53

2. One Methodology, Two Approaches .....................................55

II. Case Studies: Gaps and Inconsistencies in the CCL...................................56

A. Late Acceptance Rules ............................................................57

1. Late Acceptance: Counteroffer or Effective Acceptance? ........58

2. Late Acceptance by Late Performance ...................................59

3. Survey of National and International Rules of Late Acceptance

a. German Law ..............................................................60

b. American Common Law ..................................................61

c. Uniform Commercial Code.............................................63

d. United Nations Convention on Contracts for the International Sale of Goods .........................................64

4. Comparing Counteroffer and Effective Acceptance Approaches..... .65

5. Chinese Contract Law (CCL) ................................................71

a. CCL on Late Acceptance ...............................................71

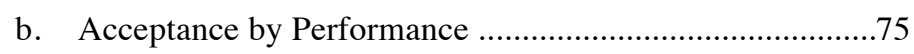

c. CCL Late Acceptance in Practice .....................................77

d. Reforming the CCL Late Acceptance Regime ..................79

B. Anticipatory Breach..............................................................83

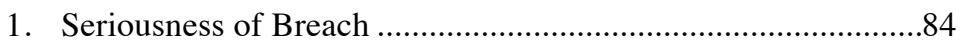

2. Express Repudiation and Reasonable Grounds for Implied

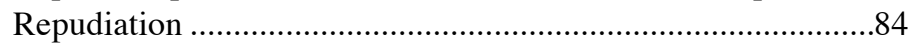

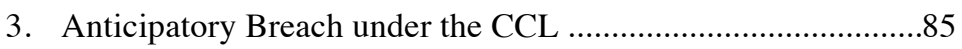




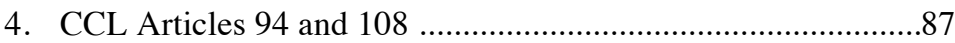

5. Defense of Insecurity in CCL Articles 68 and 69 ...................88

6. Bifurcation of Anticipatory Breach and Defense of Insecurity: Shortcomings .88

7. Reforming the CCL Anticipatory Breach-Defense of Security Regime......

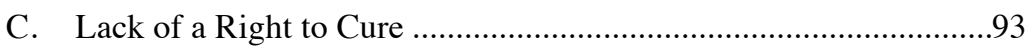

1. Modern Right to Cure ..........................................................93

2. CCL's Lack of a Right to Cure .............................................95

3. Reforming the CCL's Lack of a Right to Cure ........................97

Conclusion . .98

\section{INTRODUCTION}

The transformation of the People's Republic of China (China) into a market economy and its ascendancy into a global economic power increases the importance of studying its private laws (contract, torts, property, and unjust enrichment). The twin pillars of a market economy are private property and contract law. This Article will focus on the latter of the two pillars. The evolution of Chinese contract law provides an opportunity to study the influences of foreign laws and the formal transplantation of foreign and international law into a different cultural and legal tradition. China's formation of private contract law, beginning in the mid-1980s, is particularly interesting because of the breadth of foreign law influences involved in its development. However, the use and partial transplantation of a variety of sources can have unintended consequences. In the case of the Chinese Contract Law (CCL), it has led to a number of gaps and inconsistencies.

Part II of this Article provides the context for the more in-depth analysis of Part III. First, it provides a brief history of the evolution of modern Chinese contract law, including the variety of foreign laws used in its development. Second, it reviews the notion of "double transplantation," which in China's case involved the adoption of the United Nations Convention on Contracts for the International Sale of Goods (CISG) and the reuse of the CISG in drafting the CCL. Third, it briefly illustrates the benefits of comparative law methodology as a tool for understanding and reforming the CCL.

Part III provides case studies focusing on three inconsistent and gap-ridden areas in the CCL: late acceptance rules, anticipatory breach, and the right to cure. These case studies analyze the CCL and the multiple interpretations applied to these three areas. Part III then uses comparative law sources to recommend how the CCL can be reformed to become a more consistent, rational, and comprehensive contract law.

Finally, Part IV provides some concluding remarks. 
I.

\section{BORROWING: RECEPTION AND TRANSPLANTATION IN CHINA}

The People's Republic of China has gone through a series of receptions and legal transplantations ${ }^{1}$ from foreign and international private laws since it began in earnest to transition from a planned economy to a market economy during the 1980 s. $^{2}$ In order to facilitate trade, it adopted the Foreign Economic Contract Law of 1985 (FECL) to assure foreign parties a more modern Chinese contract law would apply to their transactions. The FECL was a comprehensible contract law stylized after modern Western civil codes. In 1988, China also became an original signatory to the CISG. This demonstrated again China's willingness to follow Western-style contract law, as well as its foresight in seeing the benefits of a uniform international sales law to the emerging economic power that it was fast becoming. The westernization of Chinese contract law was also found in the Economic Contract Law (1981), General Principles of Civil Law (1986), and the Technology Contract Law (1987). In 1999, China elected to harmonize its domestic and foreign contract laws. The FECL was repealed and a uniform national contract law was enacted-the CCL. ${ }^{3}$

DOI: http://dx.doi.org/10.15779/Z38756T

*Associate Professor, Quanzhou Normal University, China. This research was supported by Fujian Social Sciences Funding Program (No. FJ2015C036).

**Huber Hurst Professor of Contract Law, University of Florida, Warrington College of Business.

1. The term "legal transplants" was coined in Alan Watson's seminal work Legal Transplants. He defined legal transplants as "the moving of a rule or system of law from one country to another." Alan Watson, Legal TRANSPlants: AN APPROACH to COMPARATIVE LAW 22 (1974). Another term used for the transference of entire legal systems is "reception." For example, scholars speak of the reception of Roman law by the emerging countries of Europe, as well as the reception of French (or German) Civil Law by other countries, including certain countries in Latin and South America. See K. ZweigerT \& H. KötZ, An InTroduction to Comparative Law 98119 (Tony Weir trans., 3d ed. 1998). The words "transplant" and "reception" can be used interchangeably. This Article uses "transplant" to refer specifically to the transfer or expression of rules and "reception" as transfer in the broader sense of the adoption of foreign law for an entire area of law (contract, criminal, civil procedure, and so forth). "Reception" can describe foreign "influences" on the entire legal system of the receiving country. For example, German law is highly respected in China and has had a strong influence on the development of Chinese private law. Even though this Article will primarily use the narrower Watsonian term "transplant," it is also referring to China's broader reception of Western legal concepts and forms of legal reasoning. This Article's focus on the transfer of written rules does not mean to discount the significance of studying the broader reception of legal ideas, which, although more abstract, can be an even more powerful force in changing a legal culture or tradition. See Jörg Fedtke, Legal Transplants, in ELGAR ENCYCLOPEDIA OF COMPARATIVE LAW 434 (Jan M. Smits ed., 2006). Jörg Fedtke notes that the two concepts are in fact closely related: "In many cases, borrowing will not result in the copying of a specific text but rather in the transplantation of an idea." Id. at 436 (emphasis added). The word borrowing is a better, more encompassing term that is broad enough to capture both formal transplantation and various other forms of influence. This terminology is especially useful in China's case, given it is a civil law country by nature that has also been influenced by common law and international private law instruments.

2. See, e.g., China's Great Economic Transformation (Loren Brandt \& Thomas G. Rawski eds., 2008) (documenting rise as a globally influential market economy).

3. The analysis in this Article is restricted to the contract law of mainland China as 
Thus, in a short period of time China received or enacted a series of Western-style contract laws - the FECL, CISG, and CCL. This Article will look at a few of the inevitable complications of such a transformation of national law. Inevitable problems in adopting foreign law may arise from: (1) translating foreign legal concepts, principles, and rules from one language to another; (2) introducing a new foreign legal regime into existing domestic legal and cultural traditions; (3) interpreting the words of a new law, which may already have particular meaning in the foreign traditions from which they came; and (4) introducing a foreign text into a country without an existing body of jurisprudence or expertise to properly and consistently apply the new law.

China's adoption of the CISG was one of the more successful receptions. One reason for this success is the wealth of international case law and commentaries Chinese legal bodies have been able to rely on in applying CISG's provisions. Currently, there is no hard evidence whether or not the Chinese courts have been adept at applying the CISG in a consistent way, rendering well-reasoned and autonomous interpretations in accordance with CISG's mandate. ${ }^{4}$ However, there is strong evidence that Chinese arbitral bodies have successfully done so. There are currently 432 published decisions, in English, of Chinese courts and arbitral bodies applying the CISG, including 336 from China's premier arbitral body, the China International Economic and Trade Arbitration Commission (CIETAC). ${ }^{5}$ The CIETAC awards have generally been well-reasoned and of high quality, showing the Commission's ability to understand and properly apply the CISG in an unbiased manner. ${ }^{6}$

The larger issue and focus of this Article is whether Chinese courts have successfully interpreted and applied the CCL. There is no simple answer to this question. There are a myriad of reasons why it is difficult to assess Chinese courts' ability to consistently apply the CCL. First, China is generically classified as a civil law country. ${ }^{7}$ As such, case law is not as important as it

represented by the CCL. It will not discuss the law of the semi-autonomous regions of Hong Kong (English common law), Macau (Macau Civil Code), or Taiwan (Civil Code of Republic of China and Portuguese civil law).

4. See United Nations Convention on Contracts for the International Sale of Goods, Apr. 11, 1980, 1489 U.N.T.S. 3 [hereinafter CISG], art. 7.

5. See China international ECONOMic AND Trade ARbitration Commission, www.cietac.org.

6. The CIETAC Awards that currently appear on the Pace CISG Database run only to April of 2008. See CISG Database, PACE L. SCH. INST. INT'L COM. L., http://www.cisg.law.pace.edu/cisg/text/casecit.html\#china (last visited on Apr. 22, 2015).

7. The civil law nature of Chinese law may be traced back to the Qin criminal laws (221-206 BC) and the subsequent laws of the Song, Yuan, Ming, and Qing dynasties. "Compiled in 1740, the 436 statutes and 1900 sub-statutes of the Great Qing Code was ("was" is grammatically incorrect here, maybe check source) the last dynastic legal code of Imperial China and, like its predecessors, was chiefly a criminal code.” DANIEL C. K. CHOW, THE LEGAL SYSTEM OF THE PEOPLE'S REPUBLIC OF CHINA 41-42 (2d ed. 2009). The civil law nature of Chinese law has been recently reaffirmed by its decision to continue the process of enacting a Chinese Civil Code (Draft CCC). See Wang Liming, Historic Characteristics of Modern Civil Code and its Codification Process, 8 TsingHUA L. REV. 6-16 (2014). 
would be in a common law country. Second, the depth of the jurisprudence surrounding the CCL is relatively limited given that the law has been on the books for a short period of time. Third, the text of the CCL has a number of gaps and inconsistencies that have made it difficult for the courts to understand and uniformly apply its rules. This Article will highlight some of these gaps and inconsistences and suggest a number of solutions that would make the CCL a more holistic and rational law.

The transplantation of law has been a common occurrence in world history. Alan Watson in his seminal book Legal Transplants states "legal transplantsthe moving of a rule or a system of law from one country to another-have been common since the earliest recorded history." 8 Roscoe Pound noted: "History of a system of law is largely a history of borrowings of legal materials from other legal systems and of assimilation of materials from outside of the law." Modern Western legal systems, and many non-Western ones, have evolved through the transplantation and assimilation of either Roman civil law or English common law. ${ }^{10}$

The theory of transference or transplantation of law is not without its critics. Pierre Legrand regarded transplantation of laws as an illusion, arguing the "impossibility of legal transplant... what can be displaced from one jurisdiction to another is, literally, a meaningless form of words." ${ }^{11}$ Despite the debate over the normative power or degree of success that legal transplants may have, a historical accounting, as noted by Alan Watson, shows that receptions of transplants and foreign law influences have been common in the evolution of legal systems. ${ }^{12}$ Successful transplantations should be measured by a relative standard, whether transplantation leads to improvements in the law of the transplanting country, and not by an absolute standard, such as whether meanings attached to the words and concepts of the transplanted law have acquired the same meaning in the country of transplantation as in the country of origin. The likelihood of relative success is largely dependent on the transplanted law, those who apply it, and the level of sensitivity afforded to the legal and cultural context of the transplanting country. ${ }^{13}$ In the end, that

8. WATSON, supra note 1 , at 21 .

9. Id. at 22 .

10. Id.

11. Pierre Legrand, The Impossibility of Legal Transplant, 4 MAASTRICHT J. EUR. \& COMP. L. 111, 120 (1997).

12. For an earlier accounting of a massive legal transplantation, see Hitoshi Aoki, Nobushige Hozumi: A Skillful Transplanter of Western Legal Thought into Japanese Soil, in RETHINKING THE MASTERS OF COMPARATIVE LAW 129 (Annelise Riles ed., 2001) (German law influences in the drafting of the Japanese Civil Code of 1898).

13. Professor Chen Lei states that in the case of legal transplantation in China and Hong Kong:

[O]ne can conclude that as long as legal ideas are sensitive to the cultural and political context, they can move freely across the continent and influence legislation and developing legal reform - realizing that the concept of law we use as our perception of law does not prevent us from establishing a universal legal theory. 
sensitivity will generate meanings and applications that vary from the law of the country from which the law was transplanted. In this context, success should be judged relative to the law prior to transplantation: is the transplanted law as interpreted and applied more consistent, more rational, and more attuned to modern commercial dealings than the prior law?

Law, whether found in a code or in case law, especially in the area of commercial law, has always had a binary relationship with the context in which it is interpreted and applied. This relationship, writ large, places the role of law in society as both a receptive and a proactive element. Commercial law, for example, generally reflects the usages, customs, and norms of commercial practice. At the same time, the law can influence the development of good practices and deter the development of exploitative behavior through what Karl Llewellyn referred to as the role of "marking out the limits of the permissible." 14 In the case of China, this binary relationship heavily favors the importance of historical but evolving customs over the strict application of formal law. In contract law, the reception of foreign and international law influences can be seen as the first step in the development of a new Chinese legal culture that combines the uniqueness of Chinese customary practice with the new formalized rules of the CCL. The transplanted law acts as a catalyst bringing about an interpretive debate as to what the transplanted law should mean, and how the legal culture should change to make it work. ${ }^{15}$

Current Chinese commercial laws reflect the influence of European civil laws, especially German law, ${ }^{16}$ and common law to a certain extent. The problem of legal transplants, as noted above, is that the text of law is easily movable from one country to the next, but legal tradition, reasoning, and theory are not so easily transplanted. Thus, legal text is taken out of the legal tradition and culture that gives it meaning and placed within (in the case of China) the

Chen Lei, Contextualizing Legal Transplants: China and Hong Kong, in METHODS OF Comparative Law 192-93 (Pier G. Monateri ed., 2012) [hereinafter Lei, Contextualizing Legal Transplants].

14. See K.N. Llewellyn, Book Review, 52 HARV. L. REV. 700, 704 (1939). For a discussion of this normative concept, see Larry A. DiMatteo, A Theory of Interpretation in the Realm of Idealism, 5 DEPAul Bus. \& COMM. L.J. 17, 26-27 (2006).

15. See Lei, Contextualizing Legal Transplant, supra note 13, at 194 (citing Gunther Teubner, Legal Irritants: Good Faith in British Law or How Unifying Law Ends up in New Divergences, MOD. L. REV. 11 (1998)).

16. Chen Lei notes, "Europe's civil law tradition shares many similar values with China's legal tradition." He explains the civil law and traditional Chinese law prefer the "generalization of principles" and more of a communitarian perspective, as opposed to the more individualistic spirit of the common law. Lei, Contextualizing Legal Transplant, supra note 13, at 197. See also Liang Huixing, The Reception of Foreign Civil Law in China, 1 Shandong U. L. Rev. 5 (2003) [hereinafter Foreign Civil Law]; Percy R. Luney Jr., Traditional and Foreign Influences: Systems of Law in China and Japan, 52 LAW \& CONTEMP. Probs. 129 (1989); Xiangmin Xu et al., The Similarities Between Civil Law Legal Family and Chinese Legal Family, 5 J. OCEAN U. OF CHINA 48 (2005). But see Mary Ip, The Revised Contract Law and Its Implications on Consumerism in China, 9 INT'L J. Bus. 42, 45 (2004) (stating that the CCL "adopted and modified certain basic elements from the common law system, such as offer and acceptance."). 
context of a different legal tradition with its own distinct legal thought and view of the role of law in society. However, through a gradual process, the original legal culture, reasoning, and theory that first animated the transplanted law can be used later to understand and nurture that law in the country of transplantation.

Professor Han Shiyuan has made such a case in the area of pre-contractual liability. ${ }^{17}$ German law has had the greatest influence on modern Chinese law. An example of this influence is China's adoption of culpa in contrahendo or bad faith negotiation, which is found in civil law but not in common law. Professor Han notes the concept of pre-contractual liability (culpa in contrahendo) was first introduced into Chinese law with the adoption of the FECL in 1985, and a notion of bad faith negotiation that is similar to culpa in contrahendo was subsequently incorporated into Articles 41 and 42 of the CCL. ${ }^{18}$ However, Han argues the ability of the Chinese courts to understand and apply such a concept depends on what he calls "theory reception." 19 A law of pre-contractual liability is more than a set of fixed rules; it is based on a broad theory of good faith. He notes CCL Articles 41 and 42 make numerous "references to foreign civil law theories and provisions," ${ }^{20}$ including Articles 2.1.15 and 2.1.16 of the UNIDROIT Principles of International Commercial Contracts (PICC), ${ }^{21}$ and Articles 2:301 and 2:302 of the Principles of European Contract Law (PECL). ${ }^{22}$ However, simply referencing other legal instruments on the principle of good faith is unlikely to effectuate a transplant of legal theory or lead to a more complete understanding of the legal concept; only education in the civil law can achieve such a level of understanding.

The CCL was intended to harmonize China's domestic w and foreign contract laws. In doing so, the drafters relied on Western-style laws such as the CISG and the PICC. Since the CISG was adopted by China in 1988, it was a natural source for "modernizing" or "westernizing" China's domestic contract law. However, the amalgamation of rules from different sources and legal traditions in creating the CCL resulted in unavoidable problems. Two problems relating to the CCL can be described as the "comprehension problem" and the "comprehensiveness problem." The comprehension problem relates to the inherent difficulty of transplanting foreign laws from one legal system to another. The severing of rules and principles from the social, economic, and political context of their development undercuts the clarity of their meaning. Hugh Collins noted an "objection to transplants of legal rules insists that legal concepts fit into clusters of concepts, which together comprise a coherent and

17. See Han Shiyuan, Culpa in Contrahendo in Chinese Contract Law, 6 TSINGHUA CHINA L. REV. 157, 158 (2014).

18. Id. at $158-59$.

19. Id. at 158 .

20. Id.

21. UNIDROIT PRinciples OF International COMmercial CONTRACts (2010) [hereinafter PICC].

22. Commission on European Contract LaW, Principles of European Contract LAW, pts. 1 \& 2 (Ole Lando \& Hugh Beale eds., combined and revised ed. 2000) [hereinafter PECL]. 
consistent set of rules and principles for the regulation of some aspect of social life." ${ }^{23}$ Therefore, transplanting a subset of a cluster of rules, or in China's case, taking rules from numerous sources, has had a fundamental impact on the CCL's comprehensibility. This use of a patchwork of different sources has led to omissions or gaps in the CCL, making it less comprehensive than it could have been.

Thus, the CCL has suffered a crisis of meaning because it was the product of partial transplants of rules uprooted from their overall conceptual schemes. China, like the countries of the former Soviet Union, adopted Western-style contract and commercial codes but has struggled to develop court systems that could place the new codes into their societal contexts. This is largely due to the courts' failure to understand the conceptual scheme behind those rules and to adapt that scheme appropriately to a new context. This type of legal know-how takes generations of legal education and practice to develop. It is beyond the scope of this Article to determine how far along the Chinese courts have moved in interpreting and applying the CCL in a consistent way.

The second problem of legal transplants-the comprehensiveness problem-is related to the subject of the current undertaking. No code, especially not one created by using numerous foreign sources, provides a complete set of rules that covers every possible real-life scenario. There are interstitial gaps and inconsistencies within the web of rules that make up contract law. These gaps are eventually worked out by the courts. However, the separation of the formal legal text from its surrounding jurisprudence makes it more difficult for the courts in the transplanting country to resolve the resulting interpretive problems. The next section will discuss in more detail these problems of transplantation in relationship to the creation of the CCL.

\section{A. China's Double Transplantation and Resulting Problems}

As noted above, China was one of the original eleven countries, along with the United States, to adopt the CISG. As an international convention, the CISG is not strictly an example of transplantation. Countries often adopt conventions in order to harmonize law internationally. Classic examples include the carriage of goods by sea conventions (Hague Rules and Hague-Visby rules) and the Convention on the Recognition and Enforcement of Foreign Arbitral Awards (New York Convention) (over 160 signatory countries). ${ }^{24}$ The CISG is the most successful attempt at harmonizing international private substantive law with eighty-four signatory countries and climbing. ${ }^{25}$ While it is not a traditional

23. H. Collins, Methods and Aims of Comparative Contract Law, 11 OXFORD J. LEGAL STUD. 396, 398 (1991).

24. See Status of Convention on the Recognition and Enforcement of Foreign Arbitral Awards, UNITED NATIONS COMM'N INT'L TRADE Law, http://www.uncitral.org/uncitral/en/uncitral_texts/arbitration/NYConvention_status.html. (last visited Nov. 1, 2015).

25. See Status of United Nations Convention on Contracts for the International Sale of 
example of transplantation, the CISG can nonetheless be seen as a pseudotransplant because it was primarily crafted from European civil law and AngloAmerican common law. As such, existing jurisprudence in the longstanding European free market legal systems equipped European countries with a high degree of judicial expertise for implementing the CISG. Also, substantial numbers of commentaries were written on the new law in a short period of time. These resources were not readily available in China. However, as noted above, Chinese arbitral tribunals have shown a surprising adeptness in applying the CISG.

The idea of double transplantation refers to the transplantation of foreign law into another legal system and then the subsequent transplantation of that law by the transplanting country to another area of its law. In the present case, the double transplantation involves the adoption of the CISG as China's international sales law and China's subsequent use of the CISG as a major source in drafting the CCL. The drafters of the CCL were heavily influenced by academic research, including studies of contract laws in the "United States, Canada, Germany, the United Kingdom, Europe and Australia." 26 Thus, the retransplantation of the CISG and the use of a variety of foreign law sources in drafting the CCL help explain the existence of inconsistencies and gaps within the CCL, as well as the difficulty of its interpretation and application by Chinese courts. The gaps and inconsistencies in the CCL will need to be resolved through an interpretive process. This process has begun with scholarly commentaries offering different interpretive "solutions" to the problems posed by the CCL. The Supreme People's Court, the highest court in China, has also issued interpretive guidelines to help guide the lower courts in developing uniform interpretations. ${ }^{27}$

This Article will enter these academic discussions by highlighting three problematic areas of the $\mathrm{CCL}$-late acceptance, anticipatory breach, and the right to cure. It will also make recommendations on how best to solve these shortcomings. The broader point of the Article is to study the issues, problems, and solutions transplantation and reception of foreign law pose when combined and introduced into a foreign legal system. The next section will briefly review comparative law methodology as a way to understand and apply the CCL.

\footnotetext{
Goods, United NATIONS COMM'N INT'L TRADE Law, http://www.uncitral.org/uncitral/en/uncitral_texts/sale_goods/1980CISG_status.html. (last visited Nov. 1, 2015).

26. CHOW, supra note 7 , at 345 .

27. See, e.g., Interpretation I of the Supreme People's Court of Several Issues Concerning the Application of the Contract Law of the People's Republic of China (promulgated by Sup. People's Ct., Dec. 19, 1999, effective Dec. 29, 1999), CLI.3.23702(EN) (Lawinfochina) (China); Interpretation of the Supreme People's Court on Issues Concerning the Application of Law for the Trial of Cases of Disputes over Sales Contracts (Sup. People's Ct., May 10, 2012, effective July 1, 2012), CLI.3.176318 (EN) (Lawinfochina) (China).
} 


\section{B. Comparative Law as an Avenue to Law Reform}

Comparative contract law research has been conducted for a number of reasons. First, it has been used as a teaching device to educate students on different legal systems, typically by focusing on the differences between the civil and common law systems. A more dense literature can be found in the comparative analysis of different civil law systems, especially between the Germanic and Franco legal traditions. ${ }^{28}$ Less literature is found comparing differences among common law systems. ${ }^{29}$ Second, comparative contract law has been used as a source in the drafting of international law instruments. The most important example of this is the drafting of the CISG, ${ }^{30}$ which drew heavily from common and civil law systems. In addition to providing a degree of supranational harmonization, the CISG has also been used as a comparative law instrument in the reformation or modernization of national laws. ${ }^{31}$ Third, comparative law can be used in legal reform at the national level. This includes various degrees of use, ranging from mere influence to "legal transplant." 32 It is this third use of comparative law that will be the focus of this Article.

\section{Perils and Virtues of the Comparative Law Methodology}

Professor Watson lists a number of "perils" and "virtues" of comparative law methodology. Under perils he lists superficiality, incompetency, unsystematic study, and temporality. ${ }^{33}$

Watson's list of perils is supported by intuition. First, unless a researcher is fully acculturated in both of the legal systems being compared, a degree of superficiality is inherent in such research. Second, there is a risk that a researcher from one legal system comparing its law to a foreign legal system's law may misinterpret the foreign law being compared, a kind of incompetency problem. Third, a selectivity problem exists because a systematic comparison of entire legal systems is beyond most researchers' abilities or scope. Thus, the researcher will analyze specific legal rules, the selection of which will be at least

28. See, e.g., H. Patrick Glenn, Legal Traditions of the WORLD 125-69 (2d ed. 2004) ("A Civil Law Tradition: The Centrality of the Person"); ZwEIGERT \& KÖTZ, supra note 1, at 74131, 132-79 ("The Romanistic Legal Family" and "The Germanic Legal Family").

29. But see, e.g., Commercial Contract Law: Transatlantic Perspectives (Larry DiMatteo et al. eds., 2013) (comparing the common law systems of the United Kingdom and United States); CoMPARATIVE CONTRACT LAW: BRITISH AND AMERICAN PERSPECTIVES (Larry DiMatteo \& Martin Hogg eds., 2015) (same).

30. CISG, supra note 4. See generally InTERnational SALES LaW: A GLOBAl Challenge (Larry A. DiMatteo ed., 2014) (comprehensive review of the CISG and its application).

31. The CISG has heavily influenced the modernization of contract and sales law in China, Germany, The Netherlands, and is likely to have similar influences in the revisions of the French, Japanese, and Spanish Civil Codes.

32. Mathias Siems, Comparative Law 191-220 (2014). Professor Siems says that there are positive and negative views of the integrity of comparative law. The positive view is exemplified in the work of Alan Watson. Siems refers to Watson as the "father of legal transplants." Id. at 195.

33. WATSON, supra note 1, at chs. 2-3. 
partially subjective in nature. This can lead to a degree of arbitrariness in the conclusions reached and a danger of generalizing from those conclusions to characterize the greater body of law. Fourth, disparity in economic and legal development between the two countries being compared may lead to a bias toward the more highly developed law or country. This may prove troublesome because a given law may be efficient at one stage of development but become inefficient at a higher stage of development. For example, a strict product liability law may not make much sense in a poor and underdeveloped country but may make sense in a highly industrialized and developed one. The two legal systems are simply at different points on the evolutionary path.

Additional perils also exist. Homeward trend is an issue, ${ }^{34}$ which occurs when a researcher from a different legal system examines the rules or lack of rules of another legal system and is subjectively prejudiced by the legal concepts of law found in the researcher's own legal system. This does not have to be an issue of temporality since the two countries being compared might be at the same level of development. The comparatist must also fully recognize the multiple interlocking systems that make up a society (economic, cultural, legal, religious, and so forth). ${ }^{35}$ Some societies may allocate certain issues to the legal realm, while others may deal with such issues through non-legal systems. The separation of legal rules from these interlocking systems commonly results in misunderstandings regarding the meanings of those rules and how they should be applied.

The authors believe the virtues of comparative law are numerous. Comparative law may be used as a method to better understand the evolution of law. It may also be used as a powerful tool for reforming law, as it provides a survey of options used in other systems. Finally, comparative law may be used to analyze the transplantation of laws from one system to another, and the subsequent application of the laws in the receiving system.

Watson notes the formal rules being transplanted are subject to interpretation by the courts of the receiving country. This sudden disconnect between text and context means the rules "may equally operate to different effect in the two societies, even though [they are] expressed in apparently similar terms." 36 This is especially the case when introducing a Western, highly formalized law into a country with non-Western economic, social, and cultural

34. The notion of "homeward trend bias" has been used in relation to the interpretation of the CISG by different national court systems. See Ingeborg Schwenzer, Divergent Interpretations: Reasons and Solutions, in INTERNATIONAL SALES LAW: A GLOBAL ChALLENGE 102, 103 (Larry A. DiMatteo ed., 2014) (identifying homeward trend as "interpreting the provisions of the CISG according to existing or merely presumed domestic counterparts").

35. See Daniel Berkowitz et al., The Transplant Effect, 51 AM. J. ComP. L. 163 (2003) (noting that the success of transplants is dependent on conforming to existing social values). See also Graham Mayeda, Appreciate the Difference: The Role of Different Domestic Norms in Law and Development Reform: Lessons from Japan and China, 51 MCGILL L.J. 547 (2006) (noting the complexity of law reform in different normative systems).

36. WATSON, supra note 1, at 20. 
norms. In China's case, a tradition exists that is heavily based on Confucianism. ${ }^{37}$ In such a system, formalized private law has historically played a far lesser role than cultural norms found in business relationships and resorting to the courts as a means of dispute resolution is disfavored. One example of this tradition is the Chinese concept of guanxi in which business transactions are regulated by informal social and status-based relational norms. Guanxi places a great deal of importance on respect, reputation, and relational networks and not on the enforcement of formalized institutional support systems, such as contractual rights. ${ }^{38}$ Thus, a comparative law analysis should also seek to study the effects of a transplanted law on existing social and cultural systems.

\section{One Methodology, Two Approaches}

There are two traditional approaches in comparative law studies-the common core approach and the "better rules" approach. ${ }^{39}$ The first approach, championed by Continental European scholars such as Rodolfo Sacco at the University of Turin ${ }^{40}$ and Rudolf Schlesinger at Cornell University in the $1950 \mathrm{~s}$ and 1960s, looks at the commonalities among different legal systems. ${ }^{41}$ The second approach analyzes the differences between legal systems and assesses which of their different rules are "better." Oxford Professor Hugh Collins describes this comparative law methodology as a "utilitarian approach to comparative law ... [which] seeks through a comparison of the legal rules and techniques of different jurisdictions the best solutions to legal problems. The aim is to identify better solutions in foreign legal systems and then to recommend their incorporation into domestic law." 42 This Article will use both approaches. A comparative analysis will be performed on the rules for late acceptance by comparing the rules of major legal systems and international law instruments. A less in-depth use of comparative law will be used in the sections on anticipatory breach and the right to cure.

37. See Patricia Pattison \& Daniel Herron, The Mountains are High and the Emperor is Far Away: Sanctity of Contract in China, 40 AM. BuS. L.J. 459, $478-79$ (2003).

38. Howard Davies et al., Guanxi and Business Practices in the People's Republic of China, in Chinese Culture, Organizational Behavior, AND InTERNATional Business MANAGEMENT 41, 43 (Ilan Alon ed., 2003) ("Without guanxi, one simply cannot get anything done."). See also Lee Mei Yi \& Paul Ellis, Insider-Outsider Perspective of Guanxi, 43 Bus. HORIZONS 25 (2000) (noting the pros and cons of guanxi).

39. See generally Ugo Mattei, The Comparative Jurisprudence of Schlesinger and Sacco: A Study in Legal Influence, in RETHINKING THE MASTERS OF COMPARATIVE LAW, supra note 12, at 238.

40. Rodolfo Sacco is one of Europe's most famous comparative law scholars. See id.

41. R. Schlesinger, Comparative law: Cases, Texts \& Materials (1950). See generally UGo Mattei et AL., SChlesinger's Comparative LaW (2009). See also Richard Buxbaum \& Ugo Mattei, Rudolph B. Schlesinger 1909-1996, 45 AM. J. CoMP. L. 1, 1-4 (1997).

42. Collins, supra note 23, at 397. 
II.

\section{CASE STUdiEs: GAPS AND INCONSISTENCIES IN THE CCL}

Formation of a contract is generally determined under an offer-acceptance paradigm. ${ }^{43}$ The CCL adopts this widely held model of contract formation. ${ }^{44}$ Before proceeding with the analysis of the CCL's late acceptance rules or lack thereof, it is important to state the obvious: contract law is a rules-based system. One area of contract law where this rules-based system is extensive is in the offer-acceptance rules of contract formation. The rule density in this area includes primary rules, exceptions to those rules, and exceptions to the exceptions. A comprehensive set of such rules answers the core questions of whether a contract has been formed, when it has been formed, and the content of the concluded contract. Weaknesses in these rules prevent the law from efficiently answering these questions. Such a weakness can be found in the CCL's late acceptance rules. ${ }^{45}$

Contracts are formed in a variety of ways, including a bilateral contract (exchange of promises), a unilateral contract (offer promise followed by acceptance by conduct or performance), or an implied-in-fact contract (conduct followed by conduct). ${ }^{46}$ The traditional contract model involves an exchange of promises either orally or in written form. The common contract formation paradigm involves the exchange of offer and acceptance, ${ }^{47}$ and common and civil laws have developed precise offer-acceptance rules relating to the formation of contracts. Under these rules, acceptance is the key communication that creates binding obligations. Generally, the civil and common laws have similar rules for the conclusion of a contract. However, the two systems have notably different rules relating to the time when an acceptance becomes effective. According to civil law, a contract is formed when an acceptance is received by the offeror. ${ }^{48}$ By contrast, a contract is concluded under common law upon the sending or dispatch of the acceptance (as long as the transmission of the acceptance is by reasonable means). Thus, a contract under common law is formed at an earlier point in time, which limits the time during which the offeror may revoke the offer. ${ }^{49}$ Despite the difference in when an acceptance is

43. Parviz Owsia, The Notion and Function of Offer and Acceptance under French and English Law, 66 TUL. L. REV. 871, 872 (1992) ("The most common mechanism of contract formation, offer and acceptance, is used as a standard tool under both [common and civil law] systems.").

44. CHOw, supra note 7, at 350 (stating that provisions of the CCL "borrow heavily from foreign law and [are] based upon an offer and acceptance model").

45. See discussion infra Part III.A.

46. E. Allan Farnsworth, Farnsworth ON CONTRACTS 205-06, 253-54 (3d ed. 2004) [hereinafter FARNSWORTH ON CONTRACTS]

47. But see Peter Huber \& Alastair Mullis, The CisG: A New TeXtBook for STUDENTS AND PRACTITIONERS 100-02 (2007) ("Conclusion of contract otherwise than by offer and acceptance").

48. PECL, supra note 22, art. 2:205 n.2.

49. FARNSWORTH ON CONTRACTS, supra note 46, at 337-38. 
considered effective, the offer-acceptance rules of common and civil law systems, including rules dealing with late acceptance, show a high degree of consistency.

The next section examines the rules and rationales relating to acceptance in the context of the CCL. It will discuss and analyze the late acceptance rules in the civil and common law systems, along with the late acceptance rules found in the CISG. It then questions the lack of similar rules in the CCL. It concludes that the CCL should be reformed to more fully address scenarios involving late acceptance, including late dispatch of acceptance and belated delivery of acceptance after a timely dispatch. Such reform would not only fill a gap in the CCL, but would also make the CCL consistent with the CISG.

\section{A. Late Acceptance Rules}

The lack of an adequate set of late acceptance rules in the CCL is puzzling given that the CISG incorporates generally recognized late acceptance rules. Again, the CISG is the law of China in international sales and was used as a primary source in writing the CCL. The CCL represents an exception to most contract law regimes in terms of not possessing a complete set of rules dealing with the issue of late acceptance. Late acceptance rules are important because they directly impact if and when a contract is formed. Late acceptance and how the law responds to it raise a number of important questions. Do the reasons for late acceptance-belated dispatch or delayed transmission-require different rules? Is late acceptance itself something that can bind a contract? Or, is late acceptance a rejection of the offer, becoming instead a counteroffer? Legal systems answer these questions differently, leading to different real-world outcomes.

This part of the Article provides a comparative analysis of late acceptance rules in German law, American law (UCC and common law of contracts), and the CISG. The Article divides the existing rules into two types-"counteroffer theory" rules and "effective acceptance theory" rules. It then reviews Chinese law and recommends the adoption of new default rules to guide the reformation of the CCL.

Both the civil and common law systems base contractual obligations on the parties' agreement to enter into a legally binding contract. As a general matter, a contract becomes binding when an acceptance reaches the offeror (except under the common law). Most international sales and contract instruments have adopted the civil law's receipt rule. ${ }^{50}$

Common law's dispatch rule limits the problem of late acceptance because the contract is binding, even if acceptance is lost or delayed in transmission, as long as it was properly sent within a reasonable period of time. However, if the dispatch is not proper-not transmitted in compliance with requirements set out in the offer, not sent by a reasonable means of transmission, not properly

50. See, e.g., CISG, supra note 4; PICC, supra note 21. 
addressed or posted, or not sent within a reasonable time-the contract is not binding until received by the offeree. If acceptance is not received due to one of the above reasons within the time stated in the offer or within a reasonable time, then it is considered a late acceptance. ${ }^{51}$ Another way of understanding late acceptance is to understand that offers self-terminate after a period of time. If acceptance is not sent under common law or received under civil law within a reasonable period of time, there cannot be a contract because the offer has lapsed. However, most legal systems provide special rules in cases of late acceptance. The following sections will address these rules.

\section{Late Acceptance: Counteroffer or Effective Acceptance?}

The first rule of effective acceptance is that it must be unconditional and unequivocal. In short, the terms and conditions of the acceptance must mimic those of the offer. Under common law, acceptance must be a "mirror image" of the offer ${ }^{52}$ The "mirror image" rule is associated with the common law doctrine that considers differences in the terms and conditions of the acceptance, relative to the offer, as a rejection of the offer. Only when acceptance meets all the conditions of the offer can it constitute an effective acceptance. Therefore, if the offeror has fixed a specific time or period for acceptance, the offeree must accept within that period of time. ${ }^{53}$ If a time or period has not been fixed in the offer, contract law implies the offeree must accept within a reasonable period of time. If the offeree does not respond to the offer within a reasonable period of time, the response will be considered a late acceptance. ${ }^{54}$

As a general rule, late acceptance, whether due to late dispatch or due to delay in transmission, is treated as a counteroffer that gives or returns the power to make a contract to the original offeror. The American Law Institute's Restatement (Second) of Contracts (Restatement), ${ }^{55}$ the American Uniform Commercial Code (UCC), and the CISG provide similar rules in cases of late acceptance. If it is obvious to the offeror the acceptance was timely and properly dispatched but was delayed in transmission, the offeror must notify the offeree of the lateness of its receipt in order to prevent the formation of a contract. ${ }^{56}$ If late acceptance is due to a belated dispatch and not a problem in transmission, then the offeror can treat the offer as lapsed, and the late dispatch constitutes a

51. RESTATEMENT (SECOND) OF CONTRACTS $§ 70$ (1981).

52. The "mirror image" rule is associated with the common law doctrine that considers differences in the terms and conditions of the acceptance, relative to the offer, as a rejection of the offer.

53. See, e.g., BÜRgERLIChes GeSETZBuCH [BGB][CIVIL CODE], Jan. 2, 2002, BundesGesetzBLAFT TEIL I [BGB. I] 42, last amended Oct. 1, 2013, § 148, translation at http://www.gesetze-im-internet.de/englisch_bgb/ (Ger.) ("If the offeror has determined a period of time for the acceptance of the offer, the acceptance may only take place within this period.").

54. HEIN KÖTZ \& AXEL FLESSNER, EUROPEAN CONTRACT LAW 33 (1997).

55. RESTATEMENT (SECOND) OF CONTRACTS (1981).

56. See John Calamari \& Joseph Perillo, The LaW of Contracts 89 (4th ed. 1998); RESTATEMENT (SECOND) OF CONTRACTS $§ 70 \mathrm{cmt}$. a (1981). 
rejection of the offer. ${ }^{57}$ However, the offeror can accept the late acceptance by sending a notice to the offeree of the offeror's intention to recognize the acceptance as binding the contract. The question then becomes whether the contract is formed when the late acceptance was sent (common law's dispatch rule), when the late acceptance was received (civil law and CISG's receipt rule), when the offeror dispatches a notification of effective late acceptance (in the case of a belated dispatch), or when the offeree receives the notification sent by the offeror. This issue will be discussed later in the Article. These general rules relating to late acceptance provide the context in which this Article reviews the CCL.

\section{Late Acceptance by Late Performance}

In a unilateral contract, the offeror invites the offeree to accept by conduct or performance. This "invitation" may be express or implied. Implied acceptance by performance may be based on prior dealings, trade usage, or business customs. ${ }^{58}$ Three questions must be answered: (1) What type of conduct or performance is needed to bind the contract-beginning performance (such as beginning the manufacture of the goods) or completing performance (such as sending existing goods), (2) what happens if the performance is delayed, or delayed after it has begun, and (3) will either scenario be considered equivalent to late acceptance in a bilateral contract? The UCC only requires the offeree to begin performance for the conduct to be considered a binding acceptance.$^{59}$ The CISG indicates that complete or near complete performance is required. ${ }^{60}$

Restatement sections 45 and 50(2) state acceptance by performance "requires that at least part of what the offer requests be performed." ${ }^{1}$ This is the case when the offer is one for a unilateral contract in which acceptance can only be effectuated by performance and not by promise..$^{62}$ Restatement section 62 is more explicit by noting that the tendering or beginning of performance is an acceptance by performance when the offer provides the offeree the choice of accepting by promise or performance.$^{63}$ The rationale given in both cases is that

57. CALAMARI \& PERILlo, supra note 56, at 89 ("[I]f an offer lapses before an acceptance becomes effective, it would seem to follow that the late acceptance is an offer").

58. Restatement (SECOND) OF CONTRACTS $\S 32,53$ (1981); U.C.C. \$2-206 (AM. LAW INST. \& UNIF. LAW COMM'N 2014).

59. See also LA. CIV. CODE ANN. art. 1939 (2015) ("When an offeror invites an offeree to accept by performance and, according to usage or the nature or the terms of the contract, it is contemplated that the performance will be completed if commenced, a contract is formed when the offeree begins the requested performance."). See also U.C.C. § 2-206(2) (AM. LAW INST. \& UNIF. LAW COMM'N 2014) ("The beginning of a requested performance is a reasonable mode of acceptance.").

60. CISG, supra note 4, art. 25 (fundamental breach).

61. RESTATEMENT (SECOND) OF CONTRACTS (1981), $\$ \S 45,50(2)$.

62. Id. $\$ 45 \mathrm{cmt}$. a.

63. Id. $\S 63$. 
the beginning of performance "operates as a promise to render complete performance. ${ }^{64}$ Acceptance by performance can be especially important under the UCC, which requires a writing (most notably under the statute of frauds) to create an enforceable contract in almost all cases. ${ }^{65}$ A notable exception to the writing requirement exists for the purchase of "specially manufactured goods" 66 where there is "either a substantial beginning of their manufacture or commitments for their procurement." 67 The question remains whether late acceptance rules apply to unilateral contracts as they do in bilateral contracts if an offeree unreasonably delays the beginning of performance. The most rational answer is that promise and conduct are both methods of acceptance and, therefore, late acceptance rules are applicable. If aware of the belated performance, the offeror should be able to treat it as a counteroffer that he is free to reject. A caveat would be the case where, despite the delay in performance, the offeree still has the ability to perform an on-time delivery. In practice, the parties would likely communicate regarding the progress of performance. If progress is unduly delayed and the parties assume a contract was formed, an alternative would be for the non-breaching party to declare an anticipatory repudiation and sue for damages.

\section{Survey of National and International Rules of Late Acceptance}

The German Civil Code (BGB) and American common law will be used as representatives of their respective legal systems. This review will also consider the rules found in the UCC and the CISG.

\section{a. German Law}

In German law, the reason for the belated acceptance-be it belated dispatch or a delay in transmission-is important to the application of late acceptance rules. The BGB's late acceptance rules are found in Articles 149 and 150. ${ }^{68}$ BGB Article 150, entitled "Law and Altered Acceptance," provides the general rule that "late acceptance of an offer is considered to be a new offer." 69 Traditionally, civil law provides that late acceptance due to belated dispatch is a counteroffer, which the original offeror is free to accept, reject, or ignore. ${ }^{70}$

64. A caveat to the acceptance by performance rule is when the offeree sends non-conforming goods not as an acceptance but as an accommodation. In that case, the offeror is free to accept or reject the goods. See U.C.C. § 2-206(1)(b) (AM. LAW INST. \& UNIF. LAW COMM’N 2014) (“[A] shipment of nonconforming goods does not constitute an acceptance if the seller seasonably notifies the buyer that the shipment is offered only as an accommodation to the buyer.").

65. Id. § 2-201.

66. Specially manufactured goods of the type that are specifically made for the buyer and "are not suitable for the sale to others in the ordinary course of seller's business." Id. \$2-201(3)(a).

67. RESTATEMENT (SECOND) OF CONTRACTS § 62 (1981).

68. BGB art. 149-50 (Ger.).

69. Id. art. 150 (The late acceptance of an offer is considered to be a new offer.).

70. See Commentary on the Unidroit PRinciples of International Commercial 
However, BGB Article 149 ("Late Receipt of a Declaration of Acceptance") places an obligation on the offeror to respond to a late acceptance if the acceptance "was sent in such a way that it would have reached him in time if it had been forwarded in the usual way" and "if the offeror ought to have recognized" the acceptance had been properly sent. ${ }^{71}$ In such cases, the offeror is required to "notify the acceptor [offeree] of the delay" within a reasonable period of time. If the offeror unduly delays in sending the notification, "the acceptance is deemed not to be late" and a contract is concluded. ${ }^{72}$

\section{b. American Common Law}

The American common law of contracts is the law of the individual state court systems. The basic principles and concepts of the common law are similar across the states, but their interpretation and application may vary. This creates majority and minority views and, in some cases, a series of minority views without a mainstream or majority view. In sum, the same terminology and rules are applied with different outcomes. The Restatement may be considered a more stable representation of American common law because it provides concise descriptions of common law rules while providing normative insights into what the law should be. American courts often reference Restatement provisions, and in some cases adopt Restatement rules. This phenomenon confirms the prescriptive role the Restatement plays in American law. ${ }^{73}$ Therefore, the Restatement will be used as representative of American common law.

The Restatement fails to provide late acceptance rules. This is predominantly due to the fact that late acceptances-whether due to a belated dispatch or a delay in transmission due to the fault of the offeree - are treated as counteroffers. ${ }^{74}$ However, if acceptance is properly dispatched in a timely fashion but is delayed or lost in transmission, a contract is formed at the time of dispatch under the common law's dispatch or "mailbox" rule. Restatement

CONTRACTS (PICC) 27273 (Stefan Vogenauer \& Jan Kleinheisterkamp eds., 2009) [hereinafter COMMENTARY ON THE PICC].

71. BGB art. 149 (Ger.)

If a declaration of acceptance received late by the offeror was sent in such a way that it would have reached him in time if it had been forwarded in the usual way, and if the offeror ought to have recognized this, he must notify the acceptor of the delay after receipt of the declaration without undue delay, unless this has already been done. If he delays the sending of the notification, the acceptance is deemed not to be late.

72. Id.

73. A classic example is the serial referencing of Section 90 of the Restatement in court decisions. Section 90 deals with liability predicated upon detrimental reliance, commonly referred to as promissory estoppel. Thus, liability premised solely on the breach of a promise has been supplemented by liability based upon reliance. Reliance damages may be awarded in cases of noncontractual promises (one-way promise). See RESTATEMENT (SECOND) OF CONTRACTS $§ 90$ (1981). E. Allan Farnsworth notes that: "Restatement Second [§ 90] states that recovery 'may be limited as justice requires,' language that is generally invoked in limiting recovery to damages based on the reliance interest." See FARNSWORTH ON CONTRACTS, supra note 46, at 180.

74. RESTATEMENT (SECOND) OF CONTRACTS $\$ 70$ (1981). 
section 63 states that an acceptance "is operative and completes the manifestation of intent as soon as put out of the offeree's possession, without regard to whether it ever reaches the offeror." 75 Ancillary to the dispatch rule is that the acceptance must be sent by means dictated by the offer. ${ }^{76}$ If the offer does not provide for the means of transmission, then the offeree must send the acceptance using a reasonable means of transmission under the circumstances, ${ }^{77}$ and the acceptance has to be "properly" dispatched (for example, correct mailing address and postage).$^{78}$ However, Restatement section 57 makes an exception where an acceptance is improperly dispatched but is received "within the time in which a properly dispatched acceptance would normally have arrived" so that it is deemed to have been "operative upon dispatch." 79 Thus, an improper dispatch of the acceptance will delay the application of the "mailbox" rule pending receipt, but if the communication is nonetheless reasonably received, then the "mailbox" rule goes into effect. The time of contract formation is then the time when the acceptance was dispatched. In the case of a delay in transmission, the fact that an acceptance is received unreasonably late is irrelevant since the contract has already been formed. The remaining issue involving the late sending of the acceptance is whether the offeror may accept the late acceptance. Restatement section 70 answers this in the negative, stating a belatedly sent acceptance is a counteroffer ${ }^{80}$

Despite the lack of necessity for late acceptance rules, a density of offeracceptance rules can be seen in Restatement sections 49 and 54. In the case of a unilateral contract where the offeror invites acceptance by performance, the offeree is not required to provide notification of the commencement of performance ${ }^{81}$ However, Restatement section 54 places such an obligation to give notice of commencement when the offeree "has reason to know that the offeror has no adequate means of learning of the performance with reasonable promptness and certainty." ${ }^{2}$ The offeree must exercise due diligence to notify the offeror of acceptance unless "the offer indicates that notification of acceptance is not required." 83 This issue of the offeree providing notice of performance in a unilateral contract is an unsettled issue in the CCL.

Another issue relates to delays in the transmission of an offer. Is the time provided for acceptance of the offer extended for a period of time equivalent to the delay in the transmission of the offer? The Restatement answers the question in the negative: "the period within which a contract can be created by

\footnotetext{
75. Id. $\S 63$.

76. Id. $\S 63(\mathrm{a})$.

77. Id. $\S 65$.

78. Id. $\S 66$.

79. Id. $\$ 57$.

80. Id. $§ 70$.

81. Id. $\$ 54$.

82. Id.

83. Id. § 54(2)(a-c).
} 
acceptance is not thereby extended if the offeree knows or has reason to know of the delay." 84 However, if the delay is due to the fault of the offeror and the "offeree neither knows nor has reason to know that there has been delay, a contract can be created by acceptance within the period which would have been permissible if the offer had been dispatched at the time that its arrival seems to indicate." 85 A reasonable interpretation of this phrase is that the time for acceptance is extended for a time equivalent to the delay.

\section{c. Uniform Commercial Code}

The UCC does not provide a full regime of offer-acceptance rules and does not contain late acceptance rules, except in cases where the offeror invites acceptance by performance (notice must still be given) and where silence can be a means of acceptance. ${ }^{86}$ Part of this absence is alleviated by the written confirmation rule, ${ }^{87}$ the writing exception for specially manufactured goods, ${ }^{88}$ and the recognition of unilateral contracts. ${ }^{89}$ The informality of transactions involving the sale of goods is evident in the core section on contract formation. Section 2-204 states a contract may be formed "in any manner sufficient to show agreement, including [by] conduct." ${ }^{90}$ It further states an agreement to enter into a contract may be recognized "even though the moment of its making is undetermined." 91 Additionally, unlike the common law of contracts, a contract may be formed even if not all the material terms have been agreed to, as long as the parties intended to form a contract and "there is a reasonably certain basis for giving an appropriate remedy." 92 Since the UCC is not considered a comprehensive or a complete preemption of the common law, the common law is used to fill in the gaps in the UCC.

Regarding acceptance by performance, a unilateral contract can be formed by the conduct of the offeree in two instances. If the offer invites acceptance by conduct or performance, the type of conduct needed to bind the contract depends on the circumstances. If the goods exist, then the offeree may accept by prompt shipment of the goods. If the goods are not in existence or are not in hand, then the "beginning of performance" is a reasonable method of acceptance. 93 However, the UCC qualifies this method by requiring that the offeror receive

\footnotetext{
84. Id. § 49.

85. Id.

86. U.C.C. § 2-206 (AM. LAW INST. \& UNIF. LAW COMM’N 2014).

87. Id. § 2-201(2).

88. Id. $\S 2-201(3)(\mathrm{a})$.

89. Id. (" $[\mathrm{U}]$ nder circumstances which reasonably indicate that the goods are for the buyer, has made either a substantial beginning of their manufacture or commitments for their procurement").

90. Id. § 2-204(1).

91. Id. § 2-204(2).

92. Id. § 2-204(3).

93. Id. § 2-201(a).
} 
notice of the beginning of performance. It states "an offeror who is not notified of acceptance within a reasonable time may treat the offer as having lapsed before acceptance." $" 94$ Thus, the contract is created by conduct but the offeree must still notify the offeror of the beginning of performance.

The requirement that the offeree notify the offeror of the beginning of performance in the case of acceptance by performance raises the same issues seen in the late acceptance by promise scenario. What if the notification is delayed in transmission and is received by the offeror belatedly? If the notice is sent belatedly, can a contract still be formed? The fact that Section 2-206(2) states that the offeror of a late notice "may" treat the offer as lapsed implies the offeror may also consider the contract as formed. Does the offeror have any responsibility to notify the offeree of the late notice in the case of a delay in transmission? The UCC does not provide answers to these questions. However, in the case where the offeror treats the offer as lapsed while knowing the offeree is continuing in its performance, it seems the offeror would be obligated to notify the offeree of the nonexistence of the contract. Again, the common law's offer-acceptance rules would apply to UCC transactions. For example, UCC Section 2-206 does not expressly preclude the offeror from revoking the offer after the beginning of performance but before receiving notice. A comment to Section 2-206 notes the importance of the common law in such situations: "Nothing in this section bars the possibility that under the common law performance begun may have an intermediate effect of temporarily barring revocation of the offer." 95 This is supported by analogy to the dispatch or "mailbox" rule that dictates a contract is formed at the time the acceptance is dispatched. In the acceptance by performance scenario, the beginning of performance is the equivalent to a dispatch. Thus, the parties have entered into a binding contract, conditional on the offeree sending the required notice. Under German law, if there is any doubt as to whether a contract has come into existence, even if there has been a commencement of performance, the contract will be judged as having not come into existence..$^{96}$

\section{d. United Nations Convention on Contracts for the International Sale of Goods}

The American common law and UCC approach view a late acceptance as a counteroffer. Some civil law countries also take this approach. For example, Article 1393 of the Civil Code of Québec states "[a]n acceptance which does not correspond substantially to the offer or which is received by the offeror after the offer has lapsed does not constitute acceptance. ${ }^{97}$ In contrast, the Italian Civil Code holds out the possibility that a late acceptance may still be an effective

\footnotetext{
94. Id. § 2-206(2).

95. Id. $\$ 2-206 \mathrm{cmt} .3$.

96. BGB § 154(1) (Ger.).

97. Civil Code of Québec, S.Q. 1991, c 64, art 1393 (Can.).
} 
acceptance..$^{98}$ The CISG adopted the Italian law approach as stated in CISG Article 21, "A late acceptance is nevertheless effective as an acceptance if without delay the offeror orally so informs the offeree or dispatches a notice to that effect."

If a letter or other writing containing a late acceptance shows that it has been sent in such circumstances that if its transmission had been normal it would have reached the offeror in due time, the late acceptance is effective as an acceptance unless, without delay, the offeror orally informs the offeree that he considers his offer as having lapsed or dispatches a notice to that effect. ${ }^{99}$

Accordingly, if the offeree is informed of the effectiveness of his late acceptance, the "lapsed" offer remains in force and leads to the formation of a contract through the late acceptance. ${ }^{100}$ This rule allows a late acceptance to be effective retroactively, so that the originally proposed contract is concluded at the time the late acceptance reached the offeror. The CISG's late acceptance rule is classified in this Article as the "effective acceptance theory" approach, which is explained further below.

\section{Comparing Counteroffer and Effective Acceptance Approaches}

What are the differences between counteroffer and effective acceptance theories of late acceptance? First, the nature of the original offeror's reply to the late acceptance is different. Under counteroffer theory, the late acceptance cannot be an effective acceptance. The offeror considers such late acceptance as a counteroffer and may or may not "accept" it. The Restatement provides "[a] late acceptance may be an offer which can be accepted by the original offeror." 101 For example, "A" offers to sell "B" a tractor for $\$ 12,000$ and states he needs to have B's answer within three days. On the fourth day, B telephones A to accept. B's response constitutes a late acceptance and a rejection of A's offer. However, A may choose to accept B's response as a counteroffer and respond, in a timely manner, indicating his intent to accept B's offer. In this case, the original offeror's reply is an "acceptance" to the counteroffer (late acceptance). However, the original offeror cannot at his election regard or render the late acceptance an effective acceptance. ${ }^{102}$ The contract is formed when the original offeror dispatches a notice of acceptance of the original offeree's counteroffer.

In effective acceptance theory, the original offeror may consider the late acceptance as an effective acceptance if the offeror, without delay, notifies the offeree to that effect. The offeror's reply is in essence a declaratory notice

98. Art. 1326 Codice civile [C.c.] (It.).

99. CISG, supra note 4, art. 21.

100. See HubER \& MULLIS, supra note 47, at 97-98.

101. RESTATEMENT (SECOND) OF CONTRACTS (1981) § $70 \mathrm{cmt} . \mathrm{b}$ (late acceptance).

102. See id. $\S 70 \mathrm{cmt}$. a ("Nor can the original offeror 'waive' his right to reject, or at his election regard the counter-offer as an acceptance.”). 
instead of an acceptance. ${ }^{103}$ Such a declaratory notice can be seen as activating the effectiveness of the late acceptance and reactivating the lapsed "offer" at the same time. Schlechtriem and Schwenzer assert: "[t]he offeror's declaration of approval therefore cures a late acceptance, even if his declaration is lost or arrives late." 104 This interpretation implies the contract is formed retroactively to the time of receipt of the late acceptance upon the dispatch of the offeror's notice.

Second, the risks of the original offeror's reply are different. As mentioned above, according to the counteroffer theory the original offeror's reply to the late acceptance is considered an "acceptance." The general rule (civil law and CISG) is that a declaration of intent (offer or acceptance) becomes effective at the point when this declaration reaches the other party. ${ }^{105}$ Therefore, if the notice fails to reach the original offeree, there is no receipt and no contract. By contrast, the common law's dispatch rule states an acceptance, with a few exceptions, is effective at the time it is sent. Thus, the offeror's ability to revoke its offer comes to an end. Under the BGB, if a revocation of the counteroffer reaches the original offeror before or at the same time that the original offeror's acceptance reaches the original offeree, no contract is formed. ${ }^{106}$ Under counteroffer theory, the risks of loss or delay of the acceptance to the counteroffer are borne by the original offeror. Therefore, if a revocation of the counteroffer were received by the original offeror during the period in which the acceptance is delayed, the receipt of the delayed acceptance would be of no consequence. According to the common law, there would be a contract since the acceptance of the counteroffer was effective upon dispatch. The fact that the revocation was received prior to the acceptance is of no consequence.

Article 21(1) of the CISG contains an exception to the CISG's general receipt rule. A declaratory notice becomes effective as long as it has been "dispatched." 107 Therefore, the risk of loss or delay of the declaratory notice is borne by the original offeree. ${ }^{108}$ This rule is in line with the common law's dispatch theory in which the effectiveness of an acceptance is triggered by its dispatch. According to CISG Article 27, such dispatch shall be made by means appropriate under the circumstances. ${ }^{109}$ Under American common law, there is

103. See SCHLEChtRIEM \& SCHWENZER: COMMENTARY ON THE UN CONVENTION ON THE InTERnATIONAL SALE OF GoOdS (CISG) 254 (Ingeborg Schwenzer ed., Oxford Univ. Press 2d ed. 2005) [hereinafter SCHLECHTRIEM \& SCHWENZER].

104. Id. at 253. See also Fritz ENDERLEIN \& DiETRICH MASKOw, INTERNATIONAL SALES LAW 104 (1992).

105. CISG, supra note 4, art. 15(1), 18(2).

106. BGB art. 130(1) (Ger.) (effectiveness of a declaration of intent to absent parties). See also CISG, supra note 4, art. 18 (2) (an acceptance of an offer becomes effective at the moment the indication of assent reaches the offeror).

107. SCHLECHTRIEM \& SCHWENZER, supra note 103, at 307, 314 .

108. See id. at 253 .

109. Id. at 307 ("However, in so far as the ideas underlying Article 27 are also relevant to communications provided for in Part II and the need for them to be dispatched or to 'reach' the addressee has been left open, it will be possible, on the basis of Article 7 (2), to apply the principle 
not much difference between counteroffer theory and effective acceptance theory in this area since the common law generally treats acceptance as effective when it is sent, not when it arrives. ${ }^{110}$

Under the effective acceptance theory, the offeree is prevented from revoking because the contract is formed when the late acceptance is received, pending the sending of a notice by the offeror informing the offeree of the effectiveness of the late acceptance (delay in transmission scenario). In effective acceptance theory, after late acceptance has been received, the offeree does not have a right to revoke if the offeror dispatches the required declaratory notice. This is similar to the common law's rule relating to an acceptance overtaking a rejection. If an acceptance is sent but is overtaken by a subsequently sent rejection, a contract is formed upon the dispatch of the acceptance, removing the right of rejection. ${ }^{111}$

The common law makes a number of exceptions to the dispatch rule for effective acceptance. First, if the offeree uses an improper form of transmitting the acceptance, improperly addresses the communication, or does not take "reasonable precautions to ensure safe transmission," 112 the acceptance becomes effective on receipt. ${ }^{113}$ Second, in cases where a rejection is sent but not yet received before the offeree changes his or her mind and sends an acceptance, the dispatch rule would work an injustice on an offeror who first receives and relies upon the rejection. In such cases, the common law subjects the acceptance to a receipt rule. ${ }^{114}$ Therefore, whichever communication, rejection or acceptance, reaches the offeror first becomes effective.

To repeat, if the acceptance is sent first, followed by a rejection, a contract is formed under the dispatch rule, but if the rejection is sent first and is overtaken by an acceptance, a contract is formed if the acceptance is received before the rejection. The rationale for the second rule is that it would be unjust not to allow the offeror to rely on the rejection if it is the first-received instrument. This seems nonsensical since one would have the same injustice if the rejection were received prior to the acceptance in the event the rejection

underlying Article 27.").

110. See RESTATEMENT (SECOND) OF CONTRACTS $§ 63$ (1981):

Unless the offer provides otherwise,

(1) an acceptance made in a manner and by a medium invited by an offer is operative and completes the manifestation of mutual assent as soon as put out of the offeree's possession, without regard to whether it ever reaches the offeror; but

(2) an acceptance under an option contract is not operative until received by the offeror.

111. See id.; FARNSWORTH ON CONTRACTS, supra note 46, at 337-38.

112. Joseph M. Perillo \& John D. CALAmari, CALAmari AND PERILLO ON CONTRACTS 112 (West Grp. 5th ed. 2003).

113. See Restatement (SECOND) OF CONTRACTS $§ \S 66-67$ (1981); FARNSWorth ON CONTRACTS, supra note 46, at 339.

114. ReStATEMENT (SECOND) OF CONTRACTS $§ 63 \mathrm{cmt}$. c, illus. 7 (1981); FARNSWORTH ON CONTRACTS, supra note 46 , at $340-41$. 
overtakes the acceptance. The rationale for not protecting the offeror in the first instance is the offeror is more likely to suffer harm if the offeree is able to opportunistically play the market. For example, the offeree sends an acceptance by regular mail, deemed to be a proper means of transmission, which takes two to three days to deliver. While the acceptance is in transmission, the offeree monitors the market and determines he can now obtain a contract at a better price. He then sends an e-mail rejection that is received prior to the acceptance in order to take advantage of the market change. This would be unfair to the offeror and, therefore, the dispatch rule remains in place. ${ }^{115}$ This is a weak argument since the same rationale can be applied to the "exception rule" (acceptance overtaking a rejection), wherein the offeree sends a rejection by regular mail, monitors the market, and then expeditiously sends an acceptance. The rational approach would be to apply to both situations (rejection overtaken by acceptance and acceptance overtaken by rejection) the rule that whichever instrument is received first should control.

Third, under counteroffer theory, unless the late acceptance (counteroffer) specifies the period allowed for the original offeror's reply, the original offeror must accept the counteroffer by dispatch within a reasonable time. ${ }^{116}$ However, under the effective acceptance approach, the offeror shall notify "without delay" of the effectiveness of the acceptance. ${ }^{117}$ The question is whether there is a difference between acceptance of a counteroffer within a reasonable time and notification of the effectiveness of a late acceptance without delay. Lando and Beale indicate the time set for acceptance of a counteroffer within a reasonable time is generally longer, under most circumstances, than the time provided for effective notice without delay in effective acceptance theory. ${ }^{118}$ Therefore, the offeror is provided additional time under counteroffer theory to speculate on market movements before accepting. However, the additional period of time provided for acceptance of a counteroffer can be terminated at any time by the original offeree's revocation of the counteroffer. ${ }^{119}$

115. Id. at 113 .

116. See Contract Law of the People's Republic of China (adopted and promulgated by the $2 \mathrm{~d}$ Sess. of the 9th Nat'1 People's Cong. Mar. 15, 1999, effective Oct. 1, 1999) [hereinafter CCL], art. 23 ("An acceptance shall reach the offeror within the time limit fixed by the offer. If no time limit is fixed by the offer, the acceptance shall reach the offeror in accordance with the following provisions: (1) if an offer is made orally, acceptance shall be made promptly unless the parties stipulate otherwise; and (2) if an offer is not made orally, the acceptance shall reach the offeror within a reasonable period of time."); BGB art. 146 (Ger.) (“An offer expires if a refusal is made to the offeror, or if no acceptance is made to this person in good time in accordance with sections 147 to 149."); CISG, supra note 4, art. 18 (2) ("An acceptance is not effective if the indication of assent does not reach the offeror within the time he has fixed or, if no time is fixed, within a reasonable time, due account being taken of the circumstances of the transaction, including the rapidity of the means of communication employed by the offeror."); RESTATEMENT (SECOND) OF CONTRACTS $§ 41$ (1981) ("An offeree's power of acceptance is terminated at the time specified in the offer, or, if no time is specified, at the end of a reasonable time.").

117. SCHLECHTRIEM \& SCHWENZER, supra note 103, at 254.

118. See PECL, supra note 22, art. 2:207.

119. CCL, supra note 116, art. 18; RESTATEMENT (SECOND) OF CONTRACTS $\$ 42$ (1981). 
In some situations, the time of acceptance is so truncated there is little opportunity for a late acceptance. The CISG proffers "an oral offer must be accepted immediately unless the circumstances indicate otherwise." ${ }^{120}$ In reality, this is no different than the general rule that an offeree must accept within a reasonable period of time. Reasonable time is determined by a contextual inquiry. The need to accept an oral offer immediately can be justified under the broader rule that an offer must be accepted within a reasonable period of time, such as prior to the termination of the telephone conversation in which the offer was made. For example, because stock and bond markets are volatile by nature, contracts are formed within seconds. A stockbroker telephones a client and states he can purchase a certain stock at a given price. The client replies by stating he needs a few minutes to look at his financials and hangs up the phone. A few moments later the client calls the stockbroker, accepts, and orders the stockbroker to purchase the stock. The problem is the offer reasonably lapsed at the time the offeree ended the first telephone conversation. By the time the client called back, the market price would have likely changed, and it would therefore have been unfair to preclude the stockbroker from selling the stock to another client after the termination of the first call.

Fourthly, differences arise concerning whether the original offeror's reply (notice) can be withdrawn. In counteroffer theory, the original offeror's reply is deemed an acceptance; however, such acceptance may be withdrawn if the withdrawal reaches the original offeree before or at the same time as the notice of acceptance. ${ }^{121}$ In effective acceptance theory, as discussed above, the original offeror's notice of effective acceptance is a declaratory notice, which becomes effective once it has been dispatched. Therefore, it seems such notice cannot be withdrawn. However, it can be argued that CISG Article 22 can be applied by analogy to the offeror's notice. ${ }^{122}$ The original offeror should be allowed to withdraw his or her notice of late acceptance if the withdrawal reaches the offeree prior to receipt of the notice. Schlechtriem and Schwenzer state: "the effectiveness of a declaration which only needs to be dispatched does not necessarily have anything to do with the declarer's being bound by his declaration." 123 They reason the notice-withdrawal scenario is analogous to the offer-revocation situation where the offeror is allowed to revoke the offer prior to the offeree's receipt of the offer. In fact, the offer may be revoked after receipt, unless the offer is determined to be an irrevocable offer. ${ }^{124}$ The issue

120. CISG, supra note 4, art. 18(2).

121. CCL, supra note 116, art. 27 ("An acceptance may be withdrawn. The withdrawal notice of the acceptance shall reach the offeror before or at the same time as the acceptance notice reaches the offeror."); CISG, supra note 4, art. 22 ("An acceptance may be withdrawn if the withdrawal reaches the offeror before or at the same time, as the acceptance would have become effective.").

122. See SCHLECHTRIEM \& SCHWENZER, supra note 103 , at $253,314$.

123. Id. at 314 .

124. Article 16(2) creates a broad firm offer rule based upon the offeror fixing an amount of time upon which the offer will remain open, under Article 16(2)(a) or even if there is not such statement or assurance if it is "reasonable for the offeree to rely on the offer as being irrevocable." 
then becomes whether the notice of late acceptance is more like an offer or an acceptance. The principle of good faith in CISG Article 7(1) supports the idea that a rule that protects the addressee of such declarations is preferred. ${ }^{125}$ However, Schlechtriem and Schwenzer make a strong case that "where the addressee is not aware of a declaration on the ground that it has not yet reached him, it should be possible to withdraw it, since he has not yet acquired any position worthy of protection." 126

The common law's dispatch rule for effective acceptance results in a different answer. The authoritative opinion is the original offeror's acceptance of a counteroffer binds the contract at the time of dispatch. Comment $\mathrm{c}$ to Restatement section 63 states that even if "the offeree has power to reclaim his acceptance from the post office or telegraph company [such an act] does not prevent the acceptance from taking effect on dispatch." 127 Therefore, it can also be argued that the offeror's notice under the effective acceptance theory is akin to an acceptance, which binds the contract upon dispatch and makes it impossible for the offeror to withdraw the notice of effective acceptance.

Lastly, the time of the conclusion of a contract varies between the two theories. In counteroffer theory, according to the principle of "reach" under the $\mathrm{BGB}$, the contract is formed when the original offeror's "acceptance" of the late acceptance reaches the original offeree. ${ }^{128}$ According to effective acceptance theory, the dispatching of the offeror's declaratory notice binds the contract retroactively to the time when the late acceptance was received. ${ }^{129}$ In contrast to the CISG and BGB, American common law treats the declaratory notice as binding the contract at the time of its dispatch. ${ }^{130}$ Therefore, depending on the applicable law a contract may be concluded at the time of the receipt of the late acceptance, at the time that the offeror dispatches a declaratory notice, or at the time that the declaratory notice reaches the offeree.

CISG, supra note 4, art. 16(2), 16(2)(b).

125. Id. art. 7(1).

126. SCHLECHTRIEM \& SCHWENZER, supra note 103, at 315.

127. RESTATEMENT (SECOND) OF CONTRACTS $§ 63 \mathrm{cmt}$. c (1981).

128. BGB art. 130 (Ger.). See also CCL, supra note 116, art. 26 ("The acceptance becomes effective when the acceptance notice reaches the offeror."); CISG, supra note 4, art. 18 (2) ("An acceptance of an offer becomes effective at the moment the indications of assent reaches the offeror."); CISG, supra note 4, art. 23 ("A contract is concluded at the moment when an acceptance of an offer becomes effective in accordance with the provision of this Convention.").

129. See SCHLECHTRIEM \& SCHWENZER, supra note 103, at 254 ("The contract is formed not when the offeror gives written notice of approval to the offeree or orally informs him thereof, but retroactively at the time when the late declaration of acceptance reached the offeror..."); see also Commentary on the Draft Convention on Contracts for the International Sale of Goods prepared by the Secretariat, at 25, art. 19 cmt. 3, U.N. Doc. A/CONF. 97/5 (March 14, 1979) ("It is the late acceptance which becomes the effective acceptance as of the moment of its receipt, even though it requires the subsequent notice to validate it."); HUBER \& MULLIS, supra note 47, at 99.

130. See RESTATEMENT (SECOND) OF CONTRACTS $\$ 63$ (1981). 


\section{Chinese Contract Law (CCL)}

Generally, the gaps in the CCL need to be filled by the courts through analogical reasoning. This could be accomplished either through the use of other rules in the CCL (internal analogical reasoning), by using other similarly situated case decisions (common law), or, as is common in commercial law, recognizing an existing trade usage to fill in the gap (rule creation). The lack of a comprehensive set of late acceptance rules in the CCL is especially troubling, since the drafters of the CCL should have anticipated such a scenario in an offeracceptance model of contract formation. A review of other national laws and international legal instruments show the BGB, CISG, and the PICC have adopted a complete set of late acceptance rules. This unnecessary gap in the CCL can be easily fixed through amendments.

\section{a. CCL on Late Acceptance}

Under CCL Article 26, acceptance becomes effective when the notice reaches the offeror. If the offer does not require a return notice or promise of acceptance, then it becomes effective when an act of acceptance is performed in light of trade practices or as indicated by the offer. The flaw in the CCL is it recognizes or can be interpreted as recognizing either the counteroffer or effective acceptance approaches. CCL Article 28 provides "if the offeree dispatches an acceptance beyond the time limit for acceptance, it shall constitute a new offer unless the offeror notifies the offeree in time that the acceptance is effective." 131 Despite the term "new offer," the rule is a reflection of effective receipt theory.

Despite the wording of Article 28, most Chinese scholars prefer the counteroffer approach. One scholar argues:

The usefulness of the proviso [in Article 28] is questionable, since the late acceptance may be deemed as a new offer. The offeror's notice of considering the late acceptance as effective, [if the law is to be re-drafted], shall be converted into 'acceptance' and the 'without delay' shall be replaced by 'in a reasonable time. ${ }^{132}$

According to the above approach, Article 28 of the CCL should be interpreted to mean a late acceptance is always a counteroffer and can never be transformed into an effective acceptance by the original offeror. ${ }^{133}$ This includes the situation where the acceptance is properly dispatched by the offeree but is delayed in transmission at no fault of the offeree. Unfortunately, Article 28 does not distinguish a late acceptance due to a delay in transmission from one sent belatedly; therefore, all late acceptances are treated the same.

131. CCL, supra note 116, art. 28.

132. Han Shiyuan, Contract Law 100 (Law Press China 3d ed. 2011).

133. See A Propositional Version with Reasons for Civil Code Draft of China 63, art. 886(1) (Liang Huixing ed., 2013) [hereinafter Liang, PROPOSITIONAL CCC]. 
Despite the wording of Article 28 and the scholarly commentary regarding it, this Article states that the effective acceptance theory is the preferable approach. ${ }^{134}$ First, compared with the counteroffer theory, effective acceptance theory protects the offeree's reasonable expectations that a contract has been formed, especially in cases of a delay in transmission. In cases where the offeree knowingly sends a belated offer, then, depending on the situation, such expectations would be unreasonable. A pitfall of the counteroffer approach is it allows the offeror additional time to act opportunistically, since counteroffer theory affords the offeror a "reasonable time" (under CCL Article 23) to respond, while the late acceptance theory requires notice "without delay." Therefore, the offeror has more time to monitor market price fluctuations before committing to the contract. At the other end, especially in the case of delayed transmission, the offeree is under the impression she has contracted at a fixed price and is unable to enter the market to stem her losses if her counteroffer is eventually rejected. ${ }^{135}$ The more time the law allows the offeror to decide, the greater the risk of speculation and uncertainty relative to the offeree. The effective acceptance theory provides greater certainty and is a more efficient rule that deters opportunistic behavior. ${ }^{136}$

As a matter of efficiency, since contract formation has already been delayed due to the late arrival of the acceptance, contract law should provide an efficient rule that requires a faster, more certain way to contract formation. In the late acceptance situation, whether by belated dispatch or delayed transmission, the offeror is given the option to conclude or not conclude the contract. This is as it should be, but this option should not be subject to abuse. That is why effective acceptance theory requires a prompt response to the receipt of the late acceptance. Unlike an acceptance containing conflicting or additional terms (counteroffer), where the offeror may need time to consider the new or different terms, the late acceptance rules only apply if the late acceptance is an unequivocal acceptance of the offer (a valid acceptance but for its lateness). In the end, the offeror should be incentivized to make a prompt decision to contract or not to contract.

Second, under the effective acceptance approach, the conclusion of a contract is determined retroactively to the time of the arrival of the late acceptance. ${ }^{137}$ This provides security in the formation of the contract in that it fixes a certain time, as opposed to having to determine when the declaratory notice is sent or received. It also freezes the ability of the offeree to change her

134. Of course, the offeree may characterize its reply to offer as a counter offer either explicitly or by referring to the offer as already lapsed. If this is the case, the effective acceptance theory cannot be applied. See COMMON EUROPEAN SALES LAW (CESL): COMMENTARY 200 (Reiner Schulze ed., 2012) [hereinafter CESL].

135. C.M. BianCA \& M.J. BONELl ET AL., COMMENTARY ON THE INTERNATIONAL SALES LAW: THE 1980 VIENNA SALES CONVENTION 193 (Guiffrè ed., 1987), http://www.cisg.law.pace.edu/cisg/biblio/farnsworth-bb21.html [hereinafter BIANCA \& BONELL].

136. See SHI JingXIA, SALES CONTRACT 58-59 (1999).

137. See KÖTZ \& FLESSNER, supra note 54, at 33. 
mind by revoking her late acceptance prior to receiving the confirmatory notice from the offeror that a contract has been reached. In this regard, the effective acceptance approach benefits the offeror.

Third, since China adopted the CISG in $1988,{ }^{138}$ any divergence between its rules and those in the CCL is inherently inefficient. The offer-acceptance rules in the CISG should have been uniformly transferred to the CCL. Unfortunately, the CISG acceptance rules transplanted to the CCL were not an exact copy, resulting in uncertainty as to their meaning in the CCL. Reforming the CCL to be consistent with the CISG would rectify this unfortunate divergence.

Lastly, the trend in the modernization of national sales laws and in international legal instruments such as the CISG has been toward adopting the effective acceptance approach. ${ }^{139}$ In the context of global efficiency, greater similarity among legal regimes will lead to more certainty, which will in turn tend to reduce impediments to international trade. However, the late acceptance rule as stated in the CISG is not without flaws. The primary flaw in Article 21 is the use of the word "dispatches," which leads to a plausible interpretation that late acceptance becomes effective at the time of the dispatch of notice by the offeror, even if it is not subsequently received by the offeree. The better interpretation is that the general theory of receipt (adopted by the CISG) places the risk of transmission on the most efficient insurer of its receipt - the sending party (offeror). The purpose of Article 21 should be read as requiring a dispatch of notice "without delay," but not as preempting the general theory of receipt adopted by the CISG. Therefore, the notice becomes effective at the time of the offeree's receipt of the notice. A complete scheme of late acceptance rules would require the notice be dispatched "without delay" and the notice received within a reasonable time from dispatch. This is possible under the CISG, as noted above, with dispatch without delay being an express rule and the necessity of its receipt (within a reasonable time) being an implied general principle of the CISG. ${ }^{140}$

Further support for the adoption or interpretation of the CCL as an effective acceptance regime, as well as a receipt rule for the purpose of sending notices to

138. See Pace Law School's list of the members of CISG. CISG Database, supra note 6, http://www.cisg.law.pace.edu/cisg/countries/cntries-China.html.

139. See, e.g., CODICE CIVIL (C.C.) art. 1326(3) (It.); Art. 6:223(1) BW (Neth.); PICC, supra note 21, art. 2.1.9(1); PECL, supra note 22, art. 2:207(1); See PRINCIPLES, DEFINITIONS AND MODEL Rules of European Private LaW - Draft Common Frame of REFERENCE (C. Von Bar et al ed., 2009), https://www.law.kuleuven.be/web/mstorme/2009_02_DCFR_OutlineEdition.pdf [hereinafter DCFR], art. II (4:207)(1).

140. The implied general rule that a communication is only effective upon receipt is derived from the CISG's offer and acceptance approach: an offer is good when it "reaches the offeree." CISG, supra note 4, art. 15(1). A withdrawal of an offer is valid "if the revocation reaches the offeree before he has dispatched an acceptance." Id. art. 16(1). An acceptance is effective "at the moment the indication of assent reaches the offeror." $I d$. art. 18(2). Thus, when the word "notice" is used, it is simply a substantive rule that notice must be given, but its effectiveness should be determined by the receipt rule. 
determine the effectiveness of the late acceptance, is found in the PICC. The PICC follows the effective acceptance theory of the CISG, but uses the word "reach" instead of "dispatch" when referring to the sending of notice by the offeror. PICC provides "[a] late acceptance is nevertheless effective as an acceptance if without undue delay the offeror so informs the offeree or gives notice to that effect." ${ }^{141}$ As to when such notice becomes effective, it states: "A notice is effective when it reaches the person to whom it is given." 142 The PECL also requires the offeror to inform the offeree of the status or effectiveness of the late acceptance. ${ }^{143} \mathrm{~A}$ comment to the PECL's late acceptance rules makes clear the notice must reach the offeree. ${ }^{144}$ Another comment expressly rejects the counteroffer theory:

Some legal systems treat a late acceptance as a new offer, which the offeror may accept within the time set for acceptance [within a reasonable period of time], which is often longer than the time provided in [Article 2:207(1): 'without delay']. The [PECL does] not contain such a rule. ${ }^{145}$

Therefore, whether the lateness of the acceptance is due to a belated sending or a delay in transmission, the late acceptance can still be an effective acceptance. ${ }^{146}$ The need for the offeree to receive the offeror's notice is the mainstream view supported by the receipt theory.

In sum, the CCL late acceptance rules are comprised of a variety of elements, some of which are not a good fit with others in the context of the national and international laws reviewed in this Article. First, CCL Articles 28 and 29 provide the standard bifurcated approach to late acceptance-for acceptances belatedly sent (Article 28) and cases of delayed transmission (Article 29). Article 28 adopts both the counteroffer and late acceptance approaches. Thus, a belatedly sent acceptance is a counteroffer that the original offeror has a reasonable time to accept unless the offeror "promptly" responds to accept the late acceptance (effective acceptance approach). Article 29 asserts in the delayed transmission scenario, the late acceptance is effective to conclude a contract unless the offeror promptly notifies the offeree otherwise.

\footnotetext{
141. PICC, supra note 21, art. 2.9(1).

142. Id. art. 1.9(2).

143. PECL, supra note 22, art. 2:207 (Late Acceptance).

144. Id. cmt. B (Assent to a Late Acceptance); id. illus. 1 (offeror's notice "comes to [offeree's] notice").

145. Id. cmt. D.

146. Notes to the PECL, supra note 22, indicate which laws are in accordance with Article 2:207 and which ones are not. Regarding Article 2:207(1) (belated sending of acceptance), it lists the CISG (art. 21(1)), PICC (art. 2.9(1)), BURGERLIJK WETBEOK (BW) Article 6:223(1) (Neth.), Portuguese CC (art. 229), and Codice Civil (C.c.) Article 1326(3) (It.). Those laws that treat the late acceptance (belatedly sent) as a counteroffer include BGB Section 150 and ASTIKOS KODIKAS [A.K.] [CIVIL CODE] 19(1) (Greece). In the case of late acceptance due to a delay in transmission, the PECL is in accord with the CISG (art. 21(2)) and PICC (art. 2.9(2), as well as BGB Section 149, Astikos KodiKas [A.K.] [CiVIL CODE] 190 (Greece), and BURgERLIJK WetBeOK (BW) art. 6:223(1) (Neth.).
} 
Unfortunately, Article 29 fails to include the common wording that the delay in transmission must have been obvious or known to the offeror. ${ }^{147}$

Unlike CISG Article 21(1)'s unfortunate use of the word "dispatch[es]," language in the CCL makes clearer notice provided by the offeror is good upon receipt - not upon dispatch. CCL Articles 28 and 29 require the offeror to promptly inform the offeree of the validity of said acceptance. The word "inform" indicates the offeree must actually receive the notice. This interpretation is consistent with the receipt rule, which is standardized throughout the CCL. ${ }^{148}$ Use of the effective receipt theory for both types of late acceptance would simplify these concepts by establishing a single rule - the offeror may activate the effectiveness of late acceptance if he informs the offeree to that effect "promptly" (without delay). Under this rule, notice becomes effective when it reaches the offeree, while the contract is concluded retroactively to the date when the late acceptance reaches the offeror.

Furthermore, the offeror is free to withdraw his notice before or at the same time as when the notice reaches the offeree. Alternatively, if the counteroffer approach is retained in Article 28, the sub-optimal choice in such cases is that the offeror is allowed to accept the counteroffer (late acceptance) "in a reasonable time" instead of "without delay" so that he can speculate at the offeree's expense.

\section{b. Acceptance by Performance}

The CCL recognizes unilateral contract formation in which a contract can be formed by the offeree "performing an act" in light of prior dealings between the parties, trade practices, or as otherwise indicated in the offer. ${ }^{149}$ Questions remain as to how one should define an "act," and whether the offeree needs to provide notice it has performed the required act. CCL Article 26 addresses these questions by stating: "If an acceptance needn't be notified, it becomes effective when an act of acceptance is performed in accordance with transaction practices

147. See Ye Jinqiang, System Arrangement of Delay in Transmission in Chinese Contract Law, 1 L. SCI. 88, 89-90 (2012). But see HUBER \& MULLIS, supra note 47, at 98-99.

148. See CCL, supra note 116, art. 16 (An offer becomes effective when it reaches the offeree); $i d$. art. 17 (An offer may be withdrawn, if the withdrawal notice reaches the offeree before or at the same time that the offer reaches the offeree); $i d$. art. 18 (An offer can be cancelled if the revocation reaches the offeree before the offeree sends its acceptance); $i d$. art. 20(1) (An offer can be extinguished if notice of rejection reaches the offeror); id. art. 23 (An acceptance shall reach the offeror within the period set within the offer); id. art. 24 (The time limit for acceptance commences from the moment that the offer reaches the offeree); $i d$. art. 26 (The acceptance becomes effective when its notice reaches the offeror); $i d$. art. Article 27 (Notice of withdrawal shall reach the offeror before the notice of acceptance). The articles dealing with late acceptance do not use the words "dispatch" or "receipt." CCL Article 28 (belated sending of acceptance) states: "[O]fferor informs the offeree of the effectiveness of the said acceptance promptly." CCL Article 29 (delay in transmission) states: "[O]fferor informs the offeree promptly that it does not accept the acceptance." Given the use of the receipt rule throughout the CCL formation rules, the only reasonable interpretation of Articles 28 and 29 is that the notice of effectiveness or non-effectiveness of the late acceptance must be received by the offeree.

149. See id. art. 22. 
or as required in the offer." 150 Thus, if the offer does not require notice and invites acceptance by performance, no notice is required. In determining what constitutes an "act" of acceptance, the court is to consider whether the offer provides a "definition" of the act needed to bind the contract. For example, the offer may state: "ship the goods immediately." If the offer is silent as to what constitutes an act, the court is to look at "transaction practices." 151 However, it is unclear what "transaction practices" actually entails. For example, do "transaction practices" entail prior dealings between the parties, trade usage, business custom, or some combination of these factors? The accepted interpretation of "transaction practices" includes practices developed between the parties (prior dealings). ${ }^{152}$ Chinese commentary has asserted the act of acceptance may be based upon an "established long term relationship," 153 as in the case of when silence may be a means of acceptance. ${ }^{154}$

The key issue is whether the contract becomes binding at the beginning of the offeree's performance or when the performance is completed. CCL Article 26 states acceptance occurs "when an act of acceptance is performed." A strict interpretation of this provision would find that complete performance is required. However, this would be an inefficient interpretation, since it allows the offeror to revoke his or her offer prior to the offeree's completion of performance, thereby producing wasted expenditures. Since Article 26 does not define "act of performance," a more liberal and reasonable interpretation would be the contract is binding at the beginning of performance, unless the offer states otherwise. Professor Han argues for such an approach as a way of protecting the reasonable expectations of the offeree such that as long as he commences performance within a reasonable time, he is assured that a contract has been formed and is no longer subject to revocation. ${ }^{155}$

Another issue is whether the offeree is required to notify the offeror of performance. Notice would not be required if the offeree did not provide notice in prior dealings with the offeror. As noted above, Article 26 uses the term

150. See id. art. 26.

151. Id.

152. See WANG Liming, Study On CONTRACt LAW 238 (2002) [hereinafter Liming, Study OF CONTRACT LAW].

153. SHIYUAN, CONTRACT LAW, supra note 132, at 108-09.

154. The CCL does not contain a rule that provides for an exception whereby the offeree's silence by the offeree can function as an acceptance. CCL Article 21 states "[a]n acceptance is a statement made by the offeree indicating assent to an offer." However, given that Article 26 does not require notice for acceptance by performance "in accordance with transaction practices," those same "transaction practices" should allow for acceptance by silence. See, e.g., RESTATEMENT (SECOND) OF CONTRACTS (1981) $\$ 69$ (Acceptance by Silence); CISG Article 18(1) states: "Silence or inactivity does not in itself amount to acceptance." The phrase "in itself" is interpreted to mean that usage, such as prior dealings, can make silence a means of acceptance. CISG COMMENTARY 268 (S. Kröll, L. Mistelis \& P. Perales Viscasillas ed. 2011): "Circumstances which may indicate intent to accept [by silence] the offer include the agreement of the parties to that effect, the practices established between the parties, as well as usages that are binding upon the parties on the grounds of Art. 9 [international trade usage]."

155. SHIYUAN, supra note 132, at 108. 
"transaction practices." This term, however, is confusing due to the lack of a counterpart phrase in Western contract law. Usage may refer not only to practices developed between repeat players (prior dealings), but also to industry or business usage, customs, and practices. It seems Article 26 is referring to the former type of usage. Nonetheless, usage of the latter type, in which giving notice is not customary or expected, implies failure to give notice would not prevent a contract from becoming binding. Although not stated in the CCL, this interpretation is found in Chinese commentary. ${ }^{156} \mathrm{~A}$ further question is then presented: if the offeree sends a required notice in a unilateral contract situation when is the contract formed? Commentary suggests the contract is formed not by performance but upon receipt by the offeror of notice of the commencement of the act. ${ }^{157}$

\section{c. CCL Late Acceptance in Practice}

Although Chinese case law offers sparse applications of CCL Articles 28 and 29, existing scholarship discusses the meaning and flaws of those articles. First, the bifurcation of late acceptance between the two CCL Articles is less than ideal. Taken alone, Article 28 indicates all late acceptances are counteroffers that the original offeror is free to disregard. But Article 29 indicates that if the late acceptance is due to a delayed transmission, it constitutes an effective acceptance (unless the offeror notifies the offeree otherwise). However, if the offeror expressly fixes a date upon which the acceptance must be received, a late acceptance due to a delayed transmission would be ineffective. ${ }^{158}$

Other Chinese commentary suggests the late delivery of an acceptance sent within the time allowed for acceptance is a "standard" type of late acceptance. Professor Wang Cheng emphasizes that the CCL fails to regulate the scenario in which an acceptance is sent within the period set for receipt of the acceptance (within a reasonable period of time) but is not received within the period implied in law (a reasonable period of time from the receipt of the offer). ${ }^{159}$ Therefore, by analogy to Article 29, a timely dispatch followed by untimely delivery (not due to a delay in transmission) is a late acceptance, which means it is treated as a counteroffer. That is, it is to be treated just like an acceptance that is sent late. ${ }^{160}$

In the scenario of a belated dispatch, CCL Article 28 allows the offeror to convert the counteroffer into an effective acceptance by giving timely notice to that effect. The offeror has the option to accept the "late acceptance immediately

156. See SHIYUAN, supra note 132, at 109; LIMING, STUDY ON CONTRACT LAW, supra note 152 , at 238 .

157. Id. at 121 (which of the two sources in the previous footnote does this refer to?).

158. See, e.g., BGB $\S 148$ (Ger.) ("Fixing a Period for Acceptance").

159. PRinciples of NeW CONTRACT LAW AND COMMENTS ON RELEVANT CASES 67 (Cui Jianyuan ed., 1999).

160. Id. See also SHIYUAN, supra note 132, at 100. 
or, just decide within a reasonable time whether to accept the new offer [based on market changes]." 161 Other scholars have criticized this view as embracing both the counteroffer and effective acceptance approaches to late acceptance, thus conflating the two theories. Professor Li Yongjun states:

If [we] interpret it literally, it should be that if the offeror notifies the offeree that he considers the late acceptance to be effective, then such late acceptance shall no longer constitute a counteroffer. But in the strict sense, such interpretation contradicts the rules of conclusion of a contract. ${ }^{162}$

As noted earlier, Professor Han offers an explanation for Article 28's "internal contradiction" - a late acceptance is a counteroffer but can also be an effective acceptance at the option of the offeror. ${ }^{163}$

Based on the above critique, the Draft Civil Code of the People's Republic of China (Draft Chinese Civil Code or Draft CCC), edited by Liang Huixing, suggests amending CCL Article 28 to state: "late acceptance of an offer is [always] considered to be a new offer" 164 and cannot be converted to an effective acceptance by the offeror. We argue in the next sub-section that such an approach is not optimal.

Very few Chinese scholars have commented on the meaning of the late acceptance provisions found in CCL Article 29. ${ }^{165}$ However, further analysis shows differences between Article 29 and BGB Article 149, as well as, CISG Article 21(2). Both the BGB and CISG emphasize that if the offeror does not want to be bound by a late acceptance due to late dispatch, he need not respond. However, under the BGB and CISG, if the offeror knew or "ought" to have known the late acceptance was caused by a delay in transmission, he is required

161. But even the author himself has to admit that in practice, in order to avoid the opportunistic behavior of the offeror, even when the late acceptance has been considered a new offer by the offeror, the offeror still has to accept it on time, instead of within a reasonable time. LIMING, STUdy OF CONTRACT LAW, supra note 152, at 242; see also THE DRAFT Civil CODE OF THE PeOPle's Republic of China: ENGLish TRANSLATION art. 1297 (Liang Huixing ed., 2010) [hereinafter DRAFT CCC] ("If the offeree makes an acceptance beyond the time limit for acceptance, it shall constitute a new offer unless the offeror notifies the offeree in time that the acceptance is effective.”); THE DRAFt Civil CODE OF THE PEOPLE's REPUblic OF ChINA AND ITS LEGISLATION REASONS: GENERAL PROVISIONS OF OBLIGATIONS \& CONTRACTS 223 (Wang Liming ed., 2005) [hereinafter Wang, LEGISLATION REASONS].

162. Li YONGJUN, CONTRACT LAW 121 (2004).

163. SHIYUAN, supra note 132.

164. Liang, PROPOSITIONAL CCC, supra note 133, art. 886(1), at 63-64.

165. See Wang, LEGISLATION REASONS, supra note 161, at 224 (following the provision of CCL Articles 28 and 29 and stating that if an offeree makes within the time limit for acceptance an acceptance that could reach the offeror in time under normal conditions but happens to reach the offeror beyond the time limit due to other reasons, the acceptance shall nevertheless be effective unless the offeror notifies the offeree in time and the acceptance is denied due to its delayed arrival); see also Liang, PROPOSITIONAL CCC, supra note 133, at 63-64 (noting the difference between CCL Article 29 and BGB Article 150 or CISG Article 21(2) and amending CCL Article 29 along these lines: If the offeror could know if its transmission had been normal and the late acceptance would have reached the offeror in due time, the offeror shall inform the offeree of the lateness of the acceptance without undue delay; otherwise such late acceptance shall be deemed as not being late.). 
to notify the offeree that the offer has lapsed. ${ }^{166}$ If he fails to provide notice, the late acceptance is effective and binds the contract. If the offeror did not or should not have known of the delay in transmission, he can presume the late acceptance was due to belated dispatch. ${ }^{167}$

On the other hand, CCL Article 29 does not provide such safeguards. Under CCL Article 29, as noted previously, even if the offeror does not know and could not know the offeree had dispatched the acceptance on time but had simply experienced a delay in transmission, the offeror is still obliged to notify the offeree if he does not want to be bound by the late acceptance. This places an undue burden on the offeror who reasonably believes he had received a late acceptance and is allowed to disregard it as a counteroffer. ${ }^{168}$ Professor Ye Jinqiang argues in cases where the offeror had no indication the acceptance had been delayed in transmission, the requirement of notifying the offeree of the lateness of acceptance under CCL Article 29 is not appropriate both logically and as a value judgment. ${ }^{169}$

\section{d. Reforming the CCL Late Acceptance Regime}

Both the common core and "better rule" comparative law methodologies support the effective acceptance approach, as opposed to the counteroffer approach, to late acceptance. The CCL should be reformed, or the proposed Draft Chinese Civil Code should be drafted, ${ }^{170}$ to fully embrace effective acceptance theory. That said, it must be reiterated that late acceptance cannot be adequately captured by a single rule; instead, it requires a batch of rules. This Article has discussed multiple scenarios and the mix of potential rules that may be used.

An effective reform of the CCL late acceptance rules would need to answer the following questions: (1) how the law should deal with a belatedly sent

166. See HubER \& MULLIS, supra note 47, at 99; EUROPEAN CONTRACT LAw, supra note 54, at 34 .

167. See Huber \& Mullis, supra note 47 , at $98-99$.

168. It is possible that CCL Article 29 was transplanted partially from Article 159(1) of the Civil Code of the Republic of China (Taiwan Civil Law). See DRAFT CCC, supra note 161, art. 159(1). Prior to the amendment to Article 159(1) of the Civil Code, CCL Article 29 was almost identical in establishing that there is no such obligation on the offeror "if the offeror could have known." However, Article 159 of the Civil Code of the Republic of China was amended on April 2, 1999. The amendment indicated that the original writing of Article 159 made unclear as to whether the offeror is only obligated to notify the offeree of the lateness of acceptance on the condition that the offeror could have known that the lateness was caused by a delay in transmission when the late acceptance was sent under circumstances such that it would have reached the offeror in due time had its transmission been timely. In order to minimize ambiguity and protect the rights and interests of the offeror, this amendment to Article 159(1) has provided the additional obligation of the offeror to notify the offeree "if the offeror could have known."

169. See Ye Jinqiang, supra note 147 , at 90.

170. Towards a Chinese Civil Code: Comparative and Historical Perspectives (Chen Lei \& C.H. von Rhee eds., 2012) (provides history behind the current project of the drafting and enacting a Chinese Civil Code). 
acceptance; (2) how the law should deal with a late receipt of a timely dispatched acceptance that has been delayed in transmission; (3) how the law should deal with the issue of late acceptance in a unilateral contract (acceptance by performance); (4) at what time a contract should be binding in different late acceptance scenarios; (5) what the notice obligation of the offeror in accepting or not accepting a late acceptance should be; (6) what the notice obligation of the offeree in a scenario of late acceptance by performance should be; (7) what rights the offeror should have in revoking his notice of effective acceptance; and (8) what rights the offeree should have to withdraw his late acceptance between its receipt and the offeror's dispatch of notice.

Based upon the review of late acceptance rules, the effective acceptance theory is preferable for three main reasons. ${ }^{171}$ First, compared with counteroffer theory, the effective acceptance theory better protects the offeree against offeror speculation, which is heightened under the former approach due to the extended time that the reasonable period of time standard provides. Since the offeror is entitled to choose to form a contract or not, he can make his decision in light of market changes. ${ }^{172}$ Under the effective acceptance theory, however, the offeror is not entitled to a "reasonable time" to provide notice. He must give notice of an effective acceptance "without delay." As compared to a "reasonable" time, "without delay" has been interpreted to mean a much shorter time period. ${ }^{173}$ Effective acceptance theory protects the reasonable expectations of the offeree and deters opportunistic behavior of the offeror. Thus, it is the more efficient rule. ${ }^{174}$

Second, under the effective acceptance approach, the contract is concluded at the time of arrival of the late acceptance, which is when the parties would naturally assume the contract to be binding. ${ }^{175}$

Third, since China adopted the CISG prior to enacting the CCL, the theory of effective acceptance, presented in CISG Article 21(1), was already the law in China. Professor Feng Datong correctly states:

[I]n order to favor the conclusion of [a] contract, [the] CISG has taken a flexible method to provide that under certain conditions the late acceptance can be deemed as an effective acceptance and the contract can be concluded accordingly ... If Seller is still interested in concluding a contract with Buyer, he may notify Buyer, without undue delay, that he considers Buyer's acceptance as being effective. If so, the contract is concluded accordingly, and the date of conclusion is the date when the late acceptance arrives to Seller. ${ }^{176}$

171. Of course, the offeree may characterize its reply to an offer as a counter offer either explicitly or by referring to the offer as having already lapsed. If this is the case, the effective acceptance theory cannot be applied. See CESL, supra note 134, at 200.

172. See BIANCA \& BONELL, supra note 135, at 192-93.

173. PECL, supra note 22, art. 2:207 ("Some legal systems treat a late acceptance as a new offer which the offeror may accept within the time set for acceptance which is often longer than the time [without delay] provided in paragraph 1."); see also PECL, supra note 22, at 177.

174. JINGXIA, supra note 136, at 58-59.

175. KÖTZ \& FLESSNER, supra note 54, at 33.

176. Feng Datong, International Trade LaW 51 (1995); see also Wu Jianbing et AL., 
In the interest of consistency, the divergent rules in the CISG and the CCL on late acceptance should be reconciled. Given the CCL adopted many rules directly from the CISG, ${ }^{177}$ the most reasonable solution would be to amend the CCL's late acceptance rules to be consistent with those found in the CISG.

In summary, the proposed changes to the current rules would answer the questions posed at the beginning of this Part as follows:

1. The offeror may treat an untimely dispatched acceptance as an effective acceptance by providing notice to the offeree without delay;

2. A timely dispatched acceptance that is delayed in transmission (by no fault of the offeree) should be considered an effective acceptance (unless the offeror duly notifies the offeree of the late delivery and that he is treating the offer as having lapsed);

3. In the case of a late acceptance in a unilateral contract (acceptance by performance), the offeree should be required to provide notice of a delay in performance, and the offeror should be allowed to revoke his offer without delay. In return, the offeror should give notice that the offer has lapsed, or that he intends to accept the late performance as binding the contract;

4. In both the late acceptance scenarios involving an acceptance by promise (bilateral contract), the contract should be binding at the time of the arrival of the late acceptance. In a unilateral contract, the fairest rule would be to bind the contract at the time the offeree begins performance under the presumption that the offeree will complete performance within a reasonable time;

5. In the case where there is a belated dispatch of an acceptance, the offeror has no duty to notify the offeree of the receipt of the late acceptance. The offeror should have a duty to notify the offeree of his intent to accept a late acceptance in cases where the lateness was due to a delay in transmission that the offeror knew or should have been aware of;

6. In the case in which the offeror sends a notice of effective acceptance, he should be allowed to revoke that notice in the event that the revocation reaches the offeree on or before the notice; and

7. The offeree should not be allowed to revoke the late acceptance between its receipt and offeror's dispatch of notice of effective acceptance. In such a scenario, the contract is binding retroactively to the time of receipt of the late acceptance. This should only be the case until the offeror's "without delay" period has expired. If the "without delay" period has expired, the late acceptance is not effective. ${ }^{178}$ This would also bar the original offeror from later treating the late acceptance as a counteroffer that could still be accepted within a "reasonable time."

The above set of late acceptance rules best protects the expectations of both parties. It also allows for the consummation of a contract if that is, in fact, what the parties desire. The law should recognize a presumption that the offeree is

INTERNATIONAL BUSINESS LAW 120 (2007).

177. See Han Shiyuan, Contract Law of China and CISG, 2 J. JiNAN U. 8 (2011).

178. Note, however, that in cases of belated acceptance, the offeree could conceivably insert a provision limiting the time period during which the offeror must provide notice of accepting the late acceptance. 
willing to conclude a contract with the original offeror at the time the offeree sends his late acceptance. Late acceptance rules are a way of recognizing the parties' intent to form a contract despite the late acceptance. The ability of the offeror to conclude the contract by sending notice to the offeree is equivalent to the offeree's intent in sending the late acceptance.

The question of when the contract comes into being is an important one. There are three options: (1) at the time the offeror dispatches the notice of effective acceptance; (2) at the time the offeree receives notice of offeror's acceptance; or (3) at the time the offeror receives acceptance (as long as the offeror promptly dispatches notice to the offeree).

The first option has been dismissed previously as nonsensical under the receipt theory. ${ }^{179}$ Specifically, it places the risk of delayed or lost transmission on the wrong party. The most efficient insurer is the sending party, not the receiving party. This is the rationale that pervades the civil law and the CISG's receipt rule, as opposed to the "mailbox rule" of the common law (acceptance effective upon dispatch). The second option is inconsistent with the offeror's declaration (notice) of effective acceptance. If the acceptance is effective, then under the offer-acceptance model, it binds the contract upon receipt by the offeror.

The third choice is preferred because it protects the offeror from withdrawal of the late acceptance. Treating the late acceptance as merely a counteroffer may result in injustice to the offeror. If the late acceptance is treated as a counteroffer, a subsequent revocation defeats the reasonable expectations of the original offeror intending to send notice of effective acceptance. CISG Article 16 states the right of the offeror to revoke ends upon the dispatch of the acceptance even though the acceptance is not effective upon receipt. By analogy, the offeree's right to withdraw a late acceptance should be prevented during the "without delay" period, allowing the offeror to convert the late acceptance into an effective acceptance. Furthermore, upon the offeror's dispatch of its notice of late acceptance, the right of the offeree to revoke (counteroffer theory) should be extinguished.

In the end, the particular rules adopted in relation to the offer-acceptance paradigm are less important than the adoption of a set of rules that are comprehensive and internally consistent. An established English treatise on contract law states:

[T] he phrase 'offer and acceptance' ... is not to be applied as a talisman, revealing, by a species of esoteric art, the presence of a contract ... The rules which the judges have elaborated from the premise of offer and acceptance are neither the rigid deductions of logic nor the inspiration of natural justice. They are only presumptions, drawn from experience, to be applied in so far as they serve the ultimate object of establishing the phenomena of agreement. ${ }^{180}$

179. See CISG, supra note 4, 18(2) (accepts civil law's receipt rule over the common law's dispatch or mailbox rule).

180. M. P. FURMSTON, CHESHIRE, FifOOT, AND FURMSTON's LAW OF CONTRACT 35-36 (11th ed. 1986). 
The rule changes proposed in this Article are only the first step in a process. The consistency and comprehensiveness of transplanted rules is more a creation of the interpretation of the rules than the text of the rules. ${ }^{181}$ This is especially the case, we argue, when the sources of the rules are in one language and are then translated into the language of the receiving country. It is for the courts through interpretation, or the government through amendment, to remove the gaps and inconsistencies invariably found in translated texts. Incidentally, the problem reappears when the native language version of the country of transplant (i.e., Chinese) is translated "back" into the source rules' native language.

The next section provides an example of such a problem through a discussion of anticipatory breach and adequate assurance. In the former FECL, a seemingly more demanding threshold of a "sure guarantee" was required to defeat a declaration of anticipatory breach. ${ }^{182}$ Such a standard of assurance of performance is well beyond that found in any other law. ${ }^{183}$ The English translation of the CCL has rectified such a burdensome and unwieldy standard. That said, different translations of the CCL have used a variety of phrases, such as "appropriate assurance," "adequate assurance," and "guarantee." 184 However, since the CCL fails to define "adequate," the aforementioned phrases are sufficient because they all expunge the word "sure."

\section{B. Anticipatory Breach}

"Anticipatory breach," referred to in the common law as "anticipatory repudiation," 185 is a manifestation-express or implicit-by one party to the other that the first cannot or will not perform at least some of its obligations under the contract at the time set for performance. ${ }^{186}$ In such cases, under certain

181. Simone Glanert, Speaking Language to Law: The Case of Europe, 28 LEGAL STUD. 161, 165 (2008) (when text is "translated back into the national language, this language becomes the object of an interpretation by the national judge in every specific case."). This interpretative process captures the text within the cultural and legal traditions of the transplanting country and leads to different meanings from those given the text from the country or legal system from which it was borrowed. The success of transplantation can be measured by whether the different meanings coalesce into a consistent whole.

182. See Foreign Economic Contract Law of 1985 (adopted at the 10th Sess. of the Standing Comm. of the 6th Nat'1 People's Cong. Mar. 21, 1985), English translation reprinted in 3 INT'L TAX \& Bus. LAW. 1, 46-49 (1985) [hereinafter FECL], art. 17.

183. See U.C.C. § 2-609 cmt. 4 (AM. LAW INST. \& UNIF. LAW COMM’N 2014); PECL, supra note 22 , art. 8:105 cmt. d.

184. See, e.g., Jianming Shen, Contract Law of the People's Republic of China, ST. JoHN's UNIv. (Fall 2005), http://doc.mbalib.com/view/2a6fa23d6a499f9d21c82189ce6378af.html; translated in Contract Law of the People's Republic of China, NAT'L PEOPLE'S CONG. OF CHINA, http://www.npc.gov.cn/englishnpc/Law/2007-12/11/content_1383564.htm (last accessed Mar. 16, 2016) (official translation).

185. See RESTATEMENT (SECOND) OF CONTRACTS $§ 253$ (1981) ("Effect of Repudiation as a Breach and on Other Party's Duties"); see also id. § 2-610 (“Anticipatory Repudiation”); id. § 2-611 ("Retraction of Anticipatory Repudiation").

186. See FARNSWORTH ON CONTRACTS, supra note 46, at 558. 
circumstances, the party receiving information of a prospective breach can act in in advance of the breach to repudiate the contract. This allows the non-breaching party to terminate the contract in advance of the breach (i.e., non-delivery of goods) and commence an action for damages. ${ }^{187}$ The concept of anticipatory breach was first established in Hochster v. De la Tour ${ }^{188}$ and has since been universally accepted by common law countries, civil law countries, and international private law instruments, including the CISG and the PICC. ${ }^{189}$ The rationale behind the doctrine is that the contracting party has the right to expect not only that the other party will perform when the time comes, but also that it will do nothing to substantially impair that expectation before the time comes for performance. ${ }^{190}$

\section{Seriousness of Breach}

For an anticipatory breach to have legal effect, the threatened breach must be serious and based upon credible information. According to the Restatement and the UCC, ${ }^{191}$ the prospective non-performance must be serious enough that the injured party is able to treat it as a "total breach," which is defined as a substantial impairment of the contract. ${ }^{192}$ Under the CISG, if, before the performance date, it becomes "clear that one of the parties will commit a fundamental breach of contract," the other party can declare the contract to be void. ${ }^{193}$ The PICC states that it must be "clear that there will be a fundamental non-performance." 194 Finally, the CESL more vaguely states, "the nonperformance would be such as to justify termination." 195

\section{Express Repudiation and Reasonable Grounds for Implied Repudiation}

The breach may be anticipated by words or by conduct. Usually, a breach consists of a statement of the repudiating party that it cannot or will not perform. The statement must be sufficiently affirmative such that a reasonable person

187. See id. at 565-68.

188. Hochster v. De la Tour (1853) 118 Eng. Rep. 922 (Que.).

189. BGB $§ 323$ (Ger.); CISG, supra note 4, art. 72(1); U.C.C. $\$ \S 2-610,2-611$ (AM. LAW INST. \& UNIF. LAW COMM’N 2014); RESTATEMENT (SECOND) OF CONTRACTS $§ \$ 250-257$ (1981); PICC, supra note 21, art. 7(3)(3).

190. See FARNSWORTH ON CONTRACTS, supra note 46, at 551-54.

191. RESTATEMENT (SECOND) OF CONTRACTS $§$ 250-57 (1981); U.C.C. § 2-610 (AM. LAW INST. \& UNIF. LAW COMM'N 2014).

192. RESTATEMENT (SECOND) OF CONTRACTS § 243 (1981) provides a measure for determining total breach: "a breach of non-performance [or anticipated non-performance] gives rise to a claim for total breach only if it so substantially impairs the value of the contract to the injured party." See also U.C.C. § 2-610 (AM. LAW INST. \& UNIF. LAW COMM’N 2014) ("substantially impair the value of the contract. ..").

193. CISG, supra note 4, art. 72(1).

194. PICC, supra note 21, art. 7.3.3.

195. CESL, supra note 134 , at 116. 
would understand it to mean the breach will actually occur. ${ }^{196}$ A party may repudiate by conduct as well. In that case, an anticipatory breach entails a party's voluntary affirmative act that renders the party actually or apparently unable to perform. Since the conduct must be an affirmative act, mere delay in performance is not an anticipatory breach. ${ }^{197}$

Since the act must be voluntary, inability to perform due to incompetence or financial difficulties is also not an anticipatory breach. ${ }^{198}$ However, if such circumstances give the other party reason to believe the first party will commit a breach, the other party is entitled to exercise a right to self-help by suspending its own performance until the first party performs or provides adequate security relating to the future performance. ${ }^{199}$ UCC Section 2-609(1) provides that "[w]hen reasonable grounds for insecurity arise with respect to the performance of either party the other [party] may in writing demand adequate assurance of due performance and until he receives such assurance may if commercially reasonable suspend any performance for which he has not already received the agreed return." Further, UCC Section 2-609(4) states, "[a]fter receipt of a justified demand failure to provide within a reasonable time not exceeding thirty days such assurance of due performance as is adequate under the circumstances of the particular case is a repudiation of the contract."

The repudiating party would be in breach if it does not have reasonable grounds for suspending performance or for demanding adequate assurance. ${ }^{200}$ If a party does not have reasonable grounds, the court should question whether the party nefariously made the demand in the hope of triggering a breach. This would violate the anticipating party's duty to act in accordance with the principle of good faith. ${ }^{201}$

\section{Anticipatory Breach under the CCL}

China "transplanted" the concept of anticipatory breach from its 1985 Foreign Economic Contract Law (FECL), ${ }^{202}$ which states:

A party may temporarily suspend its performance of the contract if it has conclusive evidence that the other party is unable to perform the contract.

196. See FARNSWORTH ON CONTRACTS, supra note 46, at 559 .

197. See Pappas v. Crist, 25 S.E.2d 850 (N.C. 1943) (where owner leased premises to another lessee, this was an "unequivocal and absolute renunciation of the entire agreement to make the lease to the plaintiff"); FARNSWORTH ON CONTRACTS, supra note 46, at 563-64.

198. FARNSWORTH ON CONTRACTS, supra note 46, at 564.

199. Id. at 572-73.

200. See U.C.C. \$ 2-509 cmt. 2 (AM. LAW InST. \& UNIF. LAW COMM’N 2014).

201. See U.C.C. § 1-304 (AM. LAW INST. \& UNIF. LaW Comm’N 2014); CCL, supra note 116, art. 6.

202. The FECL was promulgated on March 21, 1985, became effective as of July 1, 1985, and was simultaneously annulled when the CCL was promulgated in 1999. See generally WANG LIMING, LiABILITIES FOR BREACH OF CONTRACT 146-47 (1996); Nan Zhengxing \& Guo Dengke, Comparative Study on Anticipatory Breach, 84 CHINESE J. L. 71-76 (1993). But see Han Shiyuan \& Cui Jianyuan, Anticipatory Breach and Chinese Contract Law, 86 CHINESE J. L. $33-38$ (1993). 
However, it shall immediately inform the other party of such suspension. It shall perform the contract if and when the other party provides a sure guarantee for performance of the contract. If a party suspends performance of the contract without conclusive evidence of the other party's inability to perform the contract, it shall be liable for breach of contract. ${ }^{203}$

The FECL places a heavy burden on the non-breaching party; it substitutes the reasonableness standard ("reasonable grounds") with a "conclusive evidence" standard. The latter sets a much higher standard to advance a claim of anticipatory breach. It also severely deters its use since the anticipating party will be deemed to be in breach if its evidence is determined to be inconclusive. Furthermore, the FECL does not give the non-breaching party a right to terminate the contract.

The shortcomings of the FECL's anticipatory breach rules were at least implicitly acknowledged when China ratified the CISG in $1986 . .^{204}$ The CISG incorporates anticipatory breach in Articles 71 and 72. These articles are similar to the rules found in the American UCC. The drafters of the CCL recognized the importance of anticipatory breach, but unfortunately decided not to transplant the better, simpler rules found in the CISG. Instead, they decided to amend the rules found in the FECL. Unfortunately, these changes did not amount to a significant improvement. ${ }^{205}$ First, the changes provide a convoluted set of rules found in different places in the CCL (Articles 68, 69, 94, and 108). Second, Articles 68 and 69 retain the extreme language of "conclusive evidence," although the CCL, as interpreted, has replaced the notion of providing a "sure guarantee" found in the FECL in favor of something more reasonable, such as the need to provide "adequate assurance" of performance. ${ }^{206}$

The CCL has dual sets of rules or concepts dealing with non-performance that can easily be conflated. Anticipatory breach is found in Articles 94 and 108, while "defense of insecurity" is found in Articles 68 and 69. The rest of this section and the next one will analyze this dual system relating to a party's fear of non-performance.

The CCL rules are unclear on the relationship between "defense of insecurity" and the right to anticipatory breach. "Defense of insecurity" is a term used in Chinese law, which is different from the concept of insecurity found in the UCC and Restatement. The Restatement bases the right to declare an anticipatory breach on the appearance of reasonable grounds for insecurity with respect to the performance of the other party. As such, parties to a contract are entitled to "a continuing sense of reliance and security that the promised

203. FECL, supra note 182, art. 17.

204. China signed the CISG on September 30, 1980, which was ratified on December 11, 1986 and became effective on January 1, 1988.

205. Han Guijun \& Xiao Guangwen, Comparative Studies of Remedies for Anticipatory Breach of Contract, in HEBEI L. SCI. (2004); Li Wei \& Huang Hui, On Defense of Insecurity (Einrede der Unsicherheit) and Anticipatory Breach, in MOD. L. REV. (2002); LI YONGJUN, supra note 162 , at 594-96.

206. See Principles of NeW CONTRACT LAW AND COMMENTS ON RELEVANT CASES 316-18 (Cui Jianyuan ed., 1999). 
performance will be forthcoming when it is due." ${ }^{207}$ It provides the further reasoning that a sense of security is an implied part of the contract. Furthermore, the nature of the ground for insecurity is a factor in determining the nature, or type, of adequate assurance to be provided to remove the declaration of anticipatory repudiation. ${ }^{208}$

Unlike the UCC and Restatement, defense of insecurity in the CCL has nothing to do with anticipatory repudiation. The Chinese concept of defense of insecurity originated from the concept of Einrede der Unsicherheit ("Defence of uncertainty") in the German Civil Code. ${ }^{209}$ Under the defense of insecurity concept in the CCL (implied in CCL Articles 68 and 69), the party who should perform first may suspend his performance or even terminate the contract if certain circumstances are met (e.g., insecurity relating to the other party's reciprocal performance). There is no reciprocal right of the breaching party to provide adequate assurance. ${ }^{210}$ It is important to note Articles 68 and 69 by their express words only allow for the suspension of the contract; they do not provide for a right of termination. Rather, it is Articles 94 and 108 that allow for termination. In sum, both sets of articles are "anticipatory" in nature, but each pair of articles provides different remedies (suspension versus termination). This bifurcation serves no reasonable purpose and has caused much confusion and debate.

\section{CCL Articles 94 and 108}

The traditional notion of anticipatory breach is found in CCL Articles 94 and 108. CCL Article 94(2) states that the parties may terminate "before the period of performance expires, [if] either party clearly indicates by word or by act that it will not discharge the principal debts." CCL Article 108 states: "If either party explicitly expresses or indicates by act its intention not to perform its obligations under the contract, the other party may, before the expiration of the period of fulfillment, demand that the party in question bear the liability for breach of contract." These phrases recognize express anticipatory breach ("clearly indicates by word;" "explicitly expresses") and implied anticipatory breach ("by act;" "indicates by act"). ${ }^{211}$

It is important to note there is a difference between non-performance and delayed performance. Therefore, if the party only indicates it could not perform

207. RESTATEMENT (SECOND) OF CONTRACTS $\$ 251 \mathrm{cmt}$ a (1981) (Rationale).

208. Id. cmt. e (Nature and time of assurance).

209. BGB § 321 (Ger.).

210. See Han \& Xiao Comparative Studies of Remedies for Anticipatory Breach of Contract, supra note 205, at 38-43; Li \& Huang, On Defense of Insecurity (Einrede der Unsicherheit) and Anticipatory Breach, supra note 205, at 54-57; LI YONGJUN, supra note 162, at 594-96.

211. The Restatement gives the example of an "act" as one when there are a series of minor breaches by one of the parties; those acts may be grounds for a declaration of implied anticipatory breach. RESTATEMENT (SECOND) OF CONTRACTS $\$ 251 \mathrm{cmt}$. c (1981) (“[M]inor breaches may give reasonable grounds for a belief that there will be more serious breaches."). 
the contract in due time, the party is not liable for anticipatory breach if it can perform within a reasonable time of the due date. CCL Article 94(3) states the right to terminate commences when the delayed performance moves beyond a reasonable time after the non-performing party has been urged to perform. The language "after being urged" seems to put a duty on the non-breaching party to make a demand for performance. ${ }^{212}$ If the breaching party attempts to perform its delayed performance within a reasonable time, it would seem that under the principle of good faith ${ }^{213}$ the party would be required to keep the non-breaching party aware of the progress of that performance.

\section{Defense of Insecurity in CCL Articles 68 and 69}

As discussed above, Article 108 provides a broader rule, while Article 68 is narrower in scope. This narrowness is due to two elements. First, it allows only for suspension and not termination of the contract. However, the failure to provide a right to terminate is alleviated by Article 69, which allows the suspending party to terminate the contract after suspension of performance if the other party fails to "reinstate its capacity of performance and does not provide a sure guarantee" of performance.

Second, Article 68 permits a party that must ordinarily perform first to suspend its performance if it can provide conclusive evidence that the other party faces any of the following circumstances: (1) serious deterioration of its business conditions; (2) diversion of its properties and secret withdrawal of capital to evade debts; (3) loss of business credibility; or (4) other situations showing inability or possible inability to meet liabilities. The best that can be said for the dual systems in the CCL-defense of insecurity in Articles 68 and 69 with anticipatory breach in Article 94 and 108-is that unlike FECL Article 17 , the CCL provides a right to terminate the contract in cases of either express or implied anticipatory breach. Nevertheless, the CCL also has shortcomings. These shortcomings are discussed in the next section.

\section{Bifurcation of Anticipatory Breach and Defense of Insecurity: Shortcomings}

The two-pronged approach found in CCL Articles 94 and 108 (anticipatory breach) and Articles 68 and 69 (defense of insecurity) have numerous shortcomings, causing a great deal of confusion. First, the remedial consequences of repudiation are unclear. The CCL only provides that the nonbreaching party may terminate the contract and/or hold the repudiating party liable for breach of contract. However, there is no specific provision that allows

212. CCL, supra note 116, art. 94(3) (“[S]till fails to discharge them within a reasonable period of time after being urged").

213. See CCL, supra note 116, art. 5 ("[T]he parties shall abide by the principle of fairness in defining the rights and obligations of each party."); see also CCL, supra note 116, art. 6 ("[T]he parties must act in accordance with the principle of good faith, no matter in exercising rights or in performing obligations.”). 
the non-breaching party to suspend his performance and require the repudiating party to provide adequate assurance.

Second, taking a literal interpretation, CCL Article 108 unduly enlarges the application of anticipatory breach. Namely, it permits a non-breaching party to terminate the contract regardless of the degree of the breach (material, minor, or de minimis). As noted above, anticipatory breach under CISG Article 71 must be serious in nature: "the other party will not perform a substantial part of his obligations." However, CCL Article 108 provides that as long as one party indicates his intention not to perform his "obligations" no matter how trivial the breach, the other party is entitled to hold the first party liable for anticipatory breach. An alternative, more reasonable interpretation of the language of CCL Article 108-"will not perform its obligations under a contract"-is the party will not perform at all, or at least not in a substantial way. This interpretation would limit the power to anticipate breach for lesser degrees of nonperformance. This view is supported by the CISG, which requires a "fundamental breach" in order to avoid or terminate a contract. ${ }^{214}$

Third, the relationship between defense of insecurity and anticipatory breach is ambiguous. From the perspective of contextual interpretation and legislative history, it seems these terms, although related, are conceptually different. The defense of insecurity is transplanted from civil law, especially from BGB Article $321,{ }^{215}$ while anticipatory breach is transplanted from CISG Articles 71 and 72, as well as common law. ${ }^{216}$ However, other than the fact that defense of insecurity is only applicable to contracts in which the parties are not expected to perform concurrently, the substance of the two systems are identical in function. ${ }^{217}$ Whenever the defense of insecurity is applicable, anticipatory breach is also applicable. Despite playing similar functions, their inclusion in the same law is problematic from the perspective of interpretation since they have different origins and are found in different chapters of the CCL. Namely, Articles 68 and 69 are found in the chapter on "Fulfillment of the Contract," Article 94 is found in the chapter on "Termination of Rights and Obligations under the Contract," and Article 108 is found in the chapter on "Liability for Breach of Contract."

As a result, some Chinese courts have wrongfully based their decisions on both Articles 68 and 69 and Articles 94 and 108, while simultaneously equating anticipatory breach with defense of insecurity. ${ }^{218}$ Some Chinese courts have

214. See CISG, supra note 4, arts. 25, 49(1), 64(1).

215. BGB $\S 321$ is entitled "Defence of uncertainty."

216. Foreign Civil Law, supra note 16, at 7-13.

217. Han \& Xiao, supra note 205, at 38-43 (explaining that this is the reason some foreign scholars hold the opinion that CCL Articles 68 and 69 are the "anticipatory breach" provisions.). See also LARRY A. DiMATTEO \& LUCIEN J. DhOOge, InTERNATIONAL Business LAW: A TRANSACTIONAL APPROACH 229 (2d ed. 2006).

218. Guangzhou XX Paper Plastic Co. v. Dongguan XX Sports Goods Co., Guangdong Dongguan 2d Intermediate People's Court (2012) DEFMECZ No. 392, http://gdlawyer.chinalawinfo.com/newlaw2002/slc/SLC.asp?Db=fnl\&Gid=118621161; 
confused the different systems and held CCL Articles 94 and 108 relate to the defense of insecurity, instead of anticipatory breach. ${ }^{219}$ This is despite the fact that mainstream Chinese scholarship recognizes Articles 94 and 108 as rules pertaining to anticipatory breach. ${ }^{220}$

Fourth, while the above conflation of CCL articles may seem irrelevant because the two concepts serve the same function, the two concepts do in fact conflict.221 For example, Article 68 allows that a party "may" suspend performance in defense of insecurity. But the "may" is converted to a "must" if that party decides to terminate the contract under Article 69. According to CCL Article 69, only if the other party has failed to regain his capability of meeting its liabilities and to provide an assurance within a reasonable time, the injured party can terminate the contract. In addition, under Article 69 the non-breaching party must have conclusive evidence to believe the other party will not or cannot perform its obligations and must promptly notify the other party of the suspension. However, if the other party regains the capability to perform and provides an adequate assurance or guarantee, the non-breaching party must continue to perform the contract. ${ }^{222}$ Thus, under the defense of insecurity approach, suspension of performance is a precondition for termination..$^{223}$ However, a different result holds if the non-breaching party brings a suit against the other party based on the concept of anticipatory breach. Articles 94 and 108 provide that as long as the non-breaching party has evidence to prove that the other party has indicated by words or acts his intention to not perform his obligations, the non-breaching party may immediately terminate the contract and hold the other party liable for the breach. ${ }^{224}$

Xiamen Juying Refrigeration Entm't Co. v. Xiamen Colorful Era Entm't Mgmt. Co. Siming District $\begin{array}{lllll}\text { People's Court, } & \text { (2013) } & \text { SMCZ } & \text { No. } & \text { 1963, }\end{array}$ http://gdlawyer.chinalawinfo.com/newlaw2002/slc/SLC.asp?Db=fnl\&Gid=119560631. See also Guiding Opinions of the Supreme People's Court on Several Issues Concerning the Trial of Cases of Disputes over Civil and Commercial Contracts Under the Current Situation (promulgated by Sup. People's Ct. July 7, 2009, effective July 7, 2009).

219. See, e.g., Guiding Opinions of the Supreme People's Court on Several Issues Concerning the Trial of Cases of Disputes over Civil and Commercial Contracts Under the Current Situation (promulgated by Sup. People's Ct. July 7, 2009, effective July 7, 2009).

220. See Han \& Xiao, supra note 205, at 38-43; Foreign Civil Law, supra, note 16, at 7-13; Li \& Huang, supra note 205, at 54-57; Ye Jinqiang, Anticipatory Breach in Chinese Contract Law, $4 \mathrm{~J}$. NANJING U. 52-59 (2002).

221. Li \& Huang, supra note 205, at 54-57.

222. See Zhejiang Province Ningbo Hongtu Paper Prods. Indus. \& Trade Co. v. Zhejiang Ningbo Jingying Zhiban Color Printing Co., (Zhejiang Ningbo Intermediate People's Ct. 2011) $\begin{array}{llllll}\text { YJSCZD No. 231; } & \text { (2012) } & \text { ZYSZZ } & \text { No. } & 30 \text {, }\end{array}$ http://gdlawyer.chinalawinfo.com/newlaw2002/slc/SLC.asp?Db=fnl\&Gid=119235901.

223. See Hunan Debang Med. Co. v. Hunan Liye Gucheng Biotech. Co., (Changsha

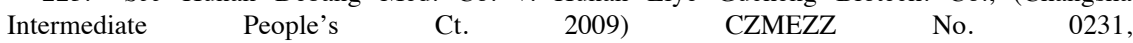
http://gdlawyer.chinalawinfo.com/newlaw2002/slc/SLC.asp?Db=fnl\&Gid=118746766.

224. Professor Han Shiyuan holds the view that based on systematic interpretation, the suspension of performance and sufficient assurance should also be preconditions for the termination of a contract due to anticipatory breach. See Han Shiyuan, The CISG and Modernisation of Chinese Contract Law, 18 COMP. L.J. THE PAC. 75 (2014) (contributions to the Study of International Trade 


\section{Reforming the CCL Anticipatory Breach-Defense of Security Regime}

In anticipation of the passage of the Chinese Civil Code, Articles 68, 69, 94, and 108 should be amended. The Draft $C C C,{ }^{225}$ in Article 915, retains the substance of the defense of insecurity currently found in CCL Articles 68 and 69. But, in Article 921, the Draft CCC amends the requirements for anticipatory breach in the following manner:

Before the expiration of the contract, if one party has indicated by words that he will not perform his principal obligations, the other party may terminate the contract.

Although Article 915 uses the phrase "principal obligations," Draft CCC Article 921 fails to define the nature of the breach in determining the appropriateness of anticipating a breach. In particular, Draft CCC Article 921 states: "[i]n case either party indicates expressly by words or by acts that he will not perform the contract, the other party may, before the expiration of the contract, hold the first party liable for breach of contract." 226 Therefore, there is still doubt, just as in CCL Article 108, about whether the Draft CCC will continue to unduly enlarge the application of anticipatory breach. ${ }^{227}$ It should also be noted the Draft CCC does not address the right to suspend performance and the requirement to provide notice of suspension.

Before the new Civil Code is adopted, Chinese courts may play an important role in resolving the deficiencies in the CCL. Recently, the court in Xiamen XX Paper Packaging Industry Co. v. Longhai XX Metal Co., Ltd. ${ }^{228}$ held:

The Defendant Longhai XX Metal Co., Ltd. had not performed its obligation of payment in accordance with the sales contract entered into by and between the plaintiff and defendant. The defendant had delayed two installments of payment. When the plaintiff required the defendant to pay the whole contract price, the defendant refused on the ground[s] of lack of money. Since the defendant failed to provide any evidence that he would pay the price when it would be due, the defendant indicates that he would not perform his obligations in accordance with the contract. The defendant's act has obviously constituted an anticipatory breach under the CCL Article 108. ${ }^{229}$

The logic behind this civil judgment is that if the defendant could provide sufficient assurance of payment when it is to become due, it is not an

Law and Alternative Dispute Resolution in the South Pacific).

225. Liang, PROPOSITIONAL CCC, supra note 133.

226. Id. at 175, 204 (explaining the Draft Civil Code tries to harmonize the two systems of Defense of Insecurity and Anticipatory Breach, instead of simply deleting one and adopting the other).

227. Id. (indicating that just like CCL Article 108, Draft CC Article 921 continues to provide that, as long as one party indicates his intention not to perform his "obligations," no matter how trivial the breach, the other party is entitled to hold the first party liable for the anticipatory breach).

228. Xiamen XX Paper Packaging Indus. Co. v. Longhai XX Metal Co., (Fujian Longhai

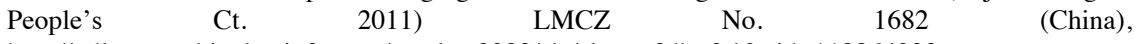
http://gdlawyer.chinalawinfo.com/newlaw2002/slc/slc.asp?db=fnl\&gid=118864232

229. Id. 
anticipatory breach. Therefore, if the defendant had provided sufficient evidence that he could pay the price, this would not be an anticipatory breach. This closes a loophole in Article 108 by confirming not all possible future breaches constitute an anticipatory breach. However, when the first party demands adequate assurance of performance, the CCL continues to place a very high burden on the "breaching" party's ability to obtain a retraction of the anticipatory breach since it must demonstrate a restored capacity to perform and provide an "adequate" guarantee of performance. ${ }^{230}$ If the other party fails to provide such assurance within a reasonable time, the first party may hold it liable for anticipatory breach.

Fortunately, courts have stepped in to try to prevent the abuse of the right to declare an anticipatory breach. First, in Shanxi Xinlei Commercial Concrete Co. v. Guangxia Construction Group Co. (2013), ${ }^{231}$ the appellate court held, consistently with this Article's argument, that slight delays of the first two payments did not constitute an anticipatory breach of future payment obligations. Second, in XX Group Co. v. Shanghai XX Concrete Products Co., ${ }^{232}$ the court recognized the non-breaching party (Shanghai $X X$ ) may choose to hold the other party (XX Group) in anticipatory breach immediately, or it may ignore the breach and wait until the time for performance passes (actual breach), which the CCL does not expressly acknowledge. This right to choose makes some sense when the object of the contract is what the non-breaching party needs. It becomes even more sensible when the object is unique (not replaceable). Therefore, the non-breaching party may try to save the contract by attempting to persuade the breaching party to retract his refusal to perform. ${ }^{233}$

In A Co. v. B Co., ${ }^{234}$ the Shanghai First Intermediate People's Court affirmed the party's choice to declare or not declare an anticipatory breach. However, it noted the non-breaching party must not misuse its right by ignoring the breach and waiting for the time for performance. ${ }^{235}$ This need for the nonbreaching party to "accept" the anticipatory breach is grounded in its duty to mitigate damages. ${ }^{236}$ The willful neglect of an anticipatory breach by the non-

\footnotetext{
230. See Liming, StUdy ON CONTRACT LAW, supra note 152, at 510-13.

231. Shanxi Xinlei Commercial Concrete Co. v. Guangxia Constr. Grp. Co. (Shanxi Higher

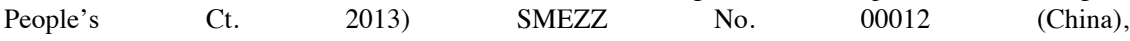
http://gdlawyer.chinalawinfo.com/newlaw2002/slc/slc.asp?db=fn1\&gid=119875238.

232. XX Grp. Co. v. Shanghai XX Concrete Prods. Co. (Shanghai 1st Intermediate People's

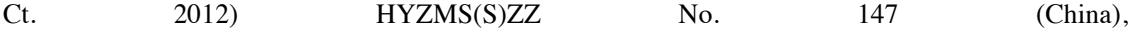
http://gdlawyer.chinalawinfo.com/newlaw2002/slc/slc.asp?db=fnl\&gid=118433657.

233. See also Shandong Precise Elec. Tech. Co. v. Guangzhou Great Power Energy \& Tech. Co. (Guangdong Guanzhou Intermediate People's Court 2013) HZFMEZZ No. 1477 (China), http://gdlawyer.chinalawinfo.com/newlaw2002/slc/SLC.asp?Db=fnl\&Gid=119630924 （same conclusion).

234. A Co. v. B Co. (Shanghai 1st Intermediate People's Ct. 2012) HYZMS(S)ZZ No. 1962 (China), http://gdlawyer.chinalawinfo.com/newlaw2002/slc/SLC.asp?Db=fnl\&Gid=118848655,.

235. Id.

236. CCL, supra note 116, art. 119 (non-breaching "party shall take proper measures to prevent from the enlargement of losses; if the other party fails to take proper measures so that the
} 
breaching party may also violate the principle of good faith. ${ }^{237}$ Therefore, the non-breaching party must accept the anticipatory breach and terminate the contract immediately so as to avoid incurring any further damages, if that is the only reasonable course of action.

The above case law shows promise that Chinese courts will, often creatively, interpret and implement provisions of the CCL in a way that produces fair and efficient outcomes. However, nothing short of statutory amendment will be able to resolve the inconsistencies, gaps, and ambiguities presented by Articles 68, 69, 94, and 108. The reform would need to: (1) define "adequate guarantee;" (2) abolish the dual system of defense of insecurity and anticipatory breach and replace it with a single, uniform set of rules; (3) apply a single set of uniform anticipatory breach rules to make clear when suspension rather than termination is appropriate; (4) prohibit the non-breaching party from ignoring an express repudiation of performance or indications of an implied repudiation, as noted in XX Group Co. ${ }^{238}$ and A Co.v. B Co. ${ }^{239}$ and (5) make clear minor breaches in most circumstances should not be grounds for anticipatory breach, especially when this tactic is used opportunistically by the non-breaching party, as noted in Shanxi Xinlei Commercial Concrete. ${ }^{240}$

\section{Lack of a Right to Cure}

The seller's right to cure refers to the breaching party's right to cure defects in its performance. Usually, in the case of the seller, this right manifests itself either through the repair or replacement of defective goods. ${ }^{241}$ The relevant laws only offered the non-breaching buyer the choice of either returning the defective goods to the seller in order to recover the full contract price, or keeping the defective goods and recovering the diminution in value of the defective goods, as compared to conforming goods. ${ }^{242}$ Thus, the seller had no right to cure the defects unless the buyer agreed to receive substituted goods from the seller.

\section{Modern Right to Cure}

The dawn of industrial production during the middle of the nineteenth century was accompanied by the mass production and supply of goods. As a consequence, repair or replacement of defective goods by the seller, as an alternative remedy to termination and price reduction, surfaced as an issue that

losses are enlarged, it may not claim any compensation as to the enlarged losses").

237. CCL, supra note 116, art. 6 ("The parties must act in accordance with the principle of good faith, no matter in exercising rights or in performing obligations.").

238. Supra note 192.

239. Supra note 194.

240. Supra note 191.

241. See Gerhard Wagner, Termination and Cure under the Common European Sales Law: Avoiding Pitfalls in Contract Remedies (June 12, 2012), http:ssrn.com/abstract=2083049 (last accessed Sep. 6, 2016).

242. Id. 
continued to challenge the civil law and the law of sales throughout subsequent decades and well into the twentieth century. In Germany, the framers of the Civil Code of 1900 failed to depart from tradition and did not insert a right of repair and replacement into statutory remedies. ${ }^{243}$ As a consequence, commercial practice developed to recognize cure by sellers as a standard remedy for delivery of non-conforming goods. ${ }^{244}$

In the United States, Karl Llewellyn ${ }^{245}$ inserted into the 1952 Draft of the $U C C$ the breaching party's right to cure. ${ }^{246}$ Since then, the right to cure has been widely accepted in both civil and common law. ${ }^{247}$ The CISG also provides for a seller's right to cure. For example, CISG Articles 34 and 37 allow the seller to cure non-conforming documents or non-conforming goods before the sales contract expires, while Article 48 offers the seller the right to cure nonconforming goods or documents for a period of time after the expiration of the delivery date set forth in the sales contract. ${ }^{248}$ PICC Article 7.1.4 expands the right to cure beyond the sale of goods to other types of contracts. ${ }^{249}$ It is generally acknowledged that the allowance of a reasonable opportunity to cure is consistent with the notion of good faith and fair dealing ${ }^{250}$ and with the desire to maintain contractual relations ${ }^{251}$ where possible and appropriate..$^{252} \mathrm{~A}$ reasonable opportunity to cure is also consistent with the spirit of mitigating loss and minimizing economic waste. ${ }^{253}$

243. See id.

244. See id.; see also SCHLECHTRIEM \& SCHWENZER, supra note 103, at 563 n.2; JAMES J. WHITE \& ROBERT S. SUMMERS, UNIFORM COMMERCIAL CODE 320 (4th ed. 1995).

245. "Llewellyn held the view that, at least in transactions between merchants, the seller deserved the privilege to cure delivery of non-conforming goods by means of a second tender." Wagner, supra note 241, at 2; see also K.N. Llewellyn, On Warranty of Quality, and Society: II, 37 COLUM. L. ReV. 341, 388-89 (1937).

246. See U.C.C. § 2-508 (AM. LAW INST. \& UNIF. LAW COMM’N 2014).

247. See, e.g., Danish Sale of Goods Act \$49, Købeloven, Act no. 102 (April 4, 1906); Sales of Goods Act (SFS 1990:931) (Köplagen) (Swed.). Even English law recognizes the seller's right to cure before or after the time for performance if time is not of the essence of the contract. See DCFR, supra note 139, 835-38. For an explanation of the right to cure in Germany, see Andreas Heldrich \& Gebhard M. Rehm, Modernisation of the German Law of Obligations: Harmonization of Civil Law and Common Law in the Recent Reform of the German Civil Code, in COMPARATIVE REMEDIES FOR BREACH OF CONTRACT 129 (Nili Cohen \& Ewan McKendrick eds., 2005).

248. See SCHLECHTRIEM \& SCHWENZER, supra note 103, at 406-08, 440-45, 562-73.

249. See COMMENTARY ON THE PICC, supra note 70, at 747-52.

250. See BIANCA \& Bonell, supra note 135, at 291; see also CCL, supra note 116, arts. 5, 6.

251. Contract maintenance is an underlying principle of the CCL, which can be found in the following articles: 8, 10, 19, 22, 28-31, 36, 40, 45, 47, 49-51, 54, 55, 61, 62, 68, 69, 73, 74, 76, 78.

252. See, e.g., Bertram Keller, Early Delivery and Seller's Right to Cure Lack of Conformity: Article 37 CISG and UNIDROIT Principles Comparative, PACE L. SCH. INST. OF INT'L AND COM. L. (June 11, 2004), http://www.jus.uio.no/pace/early_delivery_and_sellers_right_to_cure_cisg_article_37_and_upicc_co mparative.bertram_keller/sisu_manifest.html.

253. Id.; see also CCL, supra note 116, art. 119 (mitigation of damages). 


\section{CCL's Lack of a Right to Cure}

It is the authors' experience that in Chinese domestic trade practice, it is widely accepted that the breaching party may cure the non-performance before the expiration of the date for performance. In some industries, it is customary practice to provide the breaching party with the ability to repair or replace any non-performance within a fixed period of time, or within a reasonable time after the expiration of the time of performance. ${ }^{254}$ Despite the commercial practice of acknowledging the right to cure, along with the civil and common laws' adoption of such a right, the CCL has neglected to do so.

The best remedy would be to amend the CCL to include such a right or to insert such a right in the proposed Chinese Civil Code. The second best remedy would be for the court to imply such a right into the CCL. The Chinese Supreme Court has issued a judicial interpretation recognizing the right to cure in the area of construction contracts. ${ }^{255}$ For example, the Court implicitly recognized a contractor's right to cure, upholding the contract-offering party's claim for a reduction in construction price in Article 11 "if construction fails to comply with the quality requirements as agreed due to the contractor's fault, and the contractor refuses to repair, rework or modify." 256 Therefore, based on Article 11 , if the contractor agrees or offers to repair, rework or rebuild (namely, to cure the non-conformity), the non-breaching party's claim for price reduction is not supported. Professor Han has suggested a rationale for doing so by linking the right to cure to a price reduction remedy. ${ }^{257}$ According to CISG Article 50, it is clear that the seller's right to cure prevails over the buyer's right to reduce the price. ${ }^{258}$ Therefore, Han suggests Chinese courts could recognize the right to cure to limit the need for a price reduction in certain situations, with the outcome being the buyer receives conforming goods, and the seller receives the full contract price. ${ }^{259}$

254. See Wuhan Billion City Unifs. Co. v. Henan Lishen Machs. Co. (Fugou People's Ct. 2009) FMZZ No.

http://gdlawyer.chinalawinfo.com/newlaw2002/slc/slc.asp?db=fnl\&gid=117664199; Guangzhou Dingxin Elec. Tech. Co. v. Li Chengbei (Guangzhou Intermediate People's Ct. 2012) HZFMEZZ No. 2555, http://gdlawyer.chinalawinfo.com/newlaw2002/slc/SLC.asp?Db=fnl\&Gid=119660010; Wang Guangke v. Shandong Joyo Constr. Mach. Co. (Henan Kaifeng People's Ct. 2006) KMCZ No. 1721; Yancheng Gaoyang Sci. \& Tech. Co. v. Zhangjiagang Thensin Rubber \& Plastic Electromech. Co. (Nanjing Qixia People's Ct. 2010) QSCZ No. 43, http://gdlawyer.chinalawinfo.com/newlaw2002/slc/SLC.asp?Db=fnl\&Gid=118862642; Zhejiang Huzhou Suning Appliance Co. v. Yang Yongqiang (Zhejiang Huzhou People's Ct. 2009) HWSZZ No. 386, http://gdlawyer.chinalawinfo.com/newlaw2002/slc/SLC.asp?Db=fnl\&Gid=119205793.

255. Interpretation of the Supreme People's Court on Issues Concerning the Application of Law for the Trial of Cases of Dispute Over Contracts on Undertaking Construction Projects (promulgated by the Judicial Comm. Sup. People's Ct., Sept. 29, 2004, effective Jan. 1, 2005), arts. 3,11 .

256. Id. art. 11.

257. See Han Shiyuan, Logic Structure of Price Reduction, 2 TsinghUA L. Rev. 24 (2008) [hereinafter Logic Structure].

258. See SCHLECHTRIEM \& SCHWENZER, supra note 103, at 599 .

259. See Logic Structure, supra note 257, at 25. 
Another way to incorporate the right to cure into the CCL is by invoking the principle of good faith. If the breaching party can cure the non-performance without undue delay and without causing the non-breaching party unreasonable inconvenience or uncertainty, it would undermine the principle of good faith to not offer the breaching party the right to cure. ${ }^{260}$ For example, this would be the case when the breaching party's non-performance is not fundamental, and the non-breaching party claims damages instead of specific performance (repair or replacement). ${ }^{261}$ The lack of a seller's right to cure produces an inefficient outcome in the form of wasted expenditures and termination of the contractual relationship.

Including the right to cure into the CCL would also address the current imbalance between buyer and seller rights. Currently, a buyer within the CCL remedial scheme can allow the seller to cure by providing a time extension for performance (nachfrist notice), ${ }^{262}$ or it can "force" the seller to cure through a demand for specific performance. ${ }^{263}$ But, these rights are exercised purely at the discretion of the non-breaching party. As noted above, the non-breaching party may ignore these alternatives by simply declaring an avoidance (termination) of the contract and demanding damages. The CCL should provide a party the right to cure when such a cure can be effectuated promptly and without undue inconvenience to the other party. The strongest case for such a right is when the non-breaching party does not suffer any damages by allowing the breaching party to cure, whether within the contractual time for performance or by an extension of the time for performance. This outcome would align with core principles of contract law, including those of good faith, mitigation of damages, and preservation of the contractual relationship. It would also deter opportunistic behavior, such as when the buyer uses the existence of minor defects that can be easily cured to terminate the contract with the purpose of taking advantage of market changes. Fortunately, the lack of an express right to cure has not caused many cases of injustice or waste because Chinese contracts customarily stipulate such a right. ${ }^{264}$ However, the law does not require such a stipulation, leaving open possibilities whereby the parties may inadvertently forget to include such a provision, or a party with superior bargaining power may decline to give the other party such a right.

260. CCL Article 6 is a foundational principle of the CCL and states that: "The parties shall observe the principle of good faith in exercising their rights and fulfilling their obligations."

261. CCL, supra note 116, art. 111.

262. CCL, supra note 116, art. 94(3).

263. See CCL, supra note 116, arts. 110-11.

264. See, e.g., Construction Contract (Model Form) (GF-2013-0201) art. 13.2.4, http://www.mohurd.gov.cn/wbdt/xzzx/sfwb/w02015090220803046317608631.doc (last accessed Mar. 17, 2015). 


\section{Reforming the CCL's Lack of a Right to Cure}

The CCL's failure to provide a right to cure is an unfortunate gap that does not bode well for the future. The Draft $C C C$ provides a "Right to Cure" in Articles 937 and 938:

Article 937:

(1) In case any party to the contract has failed to perform the contract and if the performance period has not become due or his delayed performance has not constituted a fundamental breach, the breaching party may retender a compliant performance at his own expenses.

(2) In case the breaching party intends to cure the contract in accordance with Para. (1) herein, the following conditions shall also be met: (a) without undue delay, it gives notice indicating the proposed manner and timing of the cure; (b) cure is appropriate in the circumstances; (c) the aggrieved party has no legitimate interest in refusing cure; and (d) cure is effected promptly.

\section{Article 938:}

(1) Upon effective notice of cure, rights of the aggrieved party that are inconsistent with the breaching party's performance are suspended until the time for cure has expired.

(2) The aggrieved party may withhold performance pending cure.

(3) Notwithstanding cure, the aggrieved party retains the right to claim damages for delay as well as for any harm caused or not prevented by the cure. ${ }^{265}$

This provision is drawn from PICC Article 7.1.4. Unfortunately, the Draft $C C C$ Articles 937 and 938 leave a number of questions unanswered. First, they fail to expressly maintain the superiority of the non-breaching party's right to terminate the contract in cases of fundamental or substantial breach. ${ }^{266}$ Second, one glaring example of the need to retain this priority is in installment contracts. Because of the obligations to perform numerous installments pursuant to such a contract, one breach can lead to a pattern of breaches, thus making it easier to abuse the right to cure over time. Third, some have argued that, in order to offer consumers better protection, the right to cure should not be available if the nonbreaching party is a consumer. ${ }^{267}$ If this were the case, the consumer, instead of the merchant, would retain more freedom to choose the remedies, including repair, replacement, damages, or termination. Thus, the law should make explicit that the right to cure does not extend to consumer contracts.

265. Liang, PropositionAL CCC, supra note 133, at 211-12, 215.

266. See generally Michael Bridge, Avoidance for Fundamental Breach of Contract Under the UN Convention on the International Sale of Goods, 59 INT'L \& COMP. L.Q. 911 (2010). But for a different opinion, see PICC Article 7.1.4, which provides clearly that the right to cure shall prevail over the right to terminate. In CISG jurisprudence, this issue remains unsettled, but the prevailing view seems to be that the right to terminate (avoid) the contract prevails over the right to cure. But when judging whether the breach is fundamental, the possibility of cure shall be considered. See CISG-AC Opinion no 5, The buyer's right to avoid the contract in case of non-conforming goods or documents, 7 May 2005, Badenweiler (Ger.).

267. CESL, supra note 134 , at 490-92. 


\section{CONCLUSION}

This Article uses the CCL to explore the pitfalls of the reception and transplantation of foreign laws and influences into a different legal culture. China is an especially interesting case because its CCL reflects a myriad of influences from the civil law (especially the German BGB), common law, and the American UCC, as well as international legal instruments, such as the CISG and the PICC. In this case, the CCL drafters' study and application of this multitude of foreign and international laws, although admirable, has resulted in a less than clear and comprehensive contract law. This has caused substantial confusion, hindering the Chinese courts' abilities to properly apply the rules in a uniform manner.

This Article analyzes some of the gaps and inconsistencies in the CCL to illustrate how such borrowing can lead to a less than consistent and comprehensive contract law. The areas of study here include the CCL's late acceptance rules, its dual system of anticipatory breach and defense of insecurity, and its lack of a right to cure.

The analysis also considers the problem of "double transplantation." In the case of China, it adopted the CISG as its (domestic) international sales law, which was the first transplant. China then used the CISG as a source in drafting the CCL, the second transplant. Unfortunately, this second transplantation was only partial, since it only transferred some of the CISG rules to the CCL and used other sources for the rest of the CCL, creating a number of problems. First, partial transplantation results in unnecessary inconsistencies between the CCL and the CISG. Second, taking rules out of the context of the body of rules in which they are initially located increases the uncertainty of their meanings when transplanted into a different body of rules. This has certainly been the case in the interpretation and application of the CCL.

Since the CCL is a product of numerous foreign laws, this Article uses a comparative law methodology to try to understand the meaning of the rules in the CCL. It also uses comparative law sources to offer solutions and avenues of legal reform in order to make the CCL a more rational, consistent, and comprehensive contract law. The primary sources analyzed include the German $\mathrm{BGB}$, American UCC, and the common law as represented by the Restatement (Second) of Contracts, as well as the CISG and PICC. This Article also draws from other sources, such as the Dutch Civil Code (BW), Louisiana Civil Code, and the Civil Code of Québec, as well as the PECL and the proposed (but, ultimately rejected) CESL. Finally, this Article uses the interpretive guidelines issued by the Chinese Supreme Court and the Draft Chinese Civil Code in its analysis.

In making recommendations to reform the CCL, this Article draws on both comparative law approaches - the "common core" and the "better rules." 268 The wide array of this comparative analysis ferrets out a great deal of commonalities

268. Supra notes $39-41$ and accompanying text. 
between contract rules across different legal systems. This commonality is a powerful rationale for realigning and reforming the CCL. When comparative analysis uncovers differences in rules across legal systems, this Article recommends the use of "better rules" interpretations in the context of the existing CCL. The rules suggested here capture the reasonable expectations of both parties, encourage the efficient conclusion of contracts, and deter opportunistic behavior. 